\title{
OPEN Linking genetic determinants with salinity tolerance and ion relationships in eggplant, tomato and pepper
}

\author{
Donald L. Suarez ${ }^{1}$, Nydia Celis ${ }^{1}$, Jorge F. S. Ferreira ${ }^{1}$, Trevor Reynolds ${ }^{2} \&$ Devinder Sandhu ${ }^{1}$
}

The Solanaceae family includes commercially important vegetable crops characterized by their relative sensitivity to salinity. Evaluation of 8 eggplant (Solanum melongena), 7 tomato (Solanum lycopersicum), and 8 pepper (Capsicum spp.) heirloom cultivars from different geographic regions revealed significant variation in salt tolerance. Relative fruit yield under salt treatment varied from 52 to $114 \%$ for eggplant, 56 to $84 \%$ for tomato, and 52 to $99 \%$ for pepper. Cultivars from all three crops, except Habanero peppers, restricted $\mathrm{Na}$ transport from roots to shoots under salinity. The high salt tolerance level showed a strong association with low leaf $\mathrm{Na}$ concentration. Additionally, the leaf $\mathrm{K}$-salinity/K-control ratio was critical in determining the salinity tolerance of a genotype. Differences in relative yield under salinity were regulated by several component traits, which was consistent with the gene expression of relevant genes. Gene expression analyses using 12 genes associated with salt tolerance showed that, for eggplant and pepper, $\mathrm{Na}^{+}$exclusion was a vital component trait, while sequestration of $\mathrm{Na}^{+}$into vacuoles was critical for tomato plants. The high variability for salt tolerance found in heirloom cultivars helped characterize genotypes based on component traits of salt tolerance and will enable breeders to increase the salt tolerance of Solanaceae cultivars.

\author{
Abbreviations \\ PCR Polymerase chain reaction \\ qRT-PCR Quantitative reverse transcription-polymerase chain reaction \\ ORAC Oxygen radical absorbance capacity \\ BLAST Basic local alignment search tool
}

Agriculture is responsible for over $80 \%$ of the water consumption in the United States (https://www.usda.gov/ media/blog/2021/02/11/usda-invests-data-agricultural-irrigation-improvements). Sufficient water is vital for food security, however, groundwater aquifers worldwide are being overused ${ }^{1}$. This overuse threatens water security, welfare, and population survival ${ }^{2,3}$. Therefore, sustainability of agriculture, mainly in semi-arid regions, is highly dependent on alternative water resources, which are generally higher in salinity than freshwater. Thus, salinity is an increasing threat to vegetable production in arid and semi-arid regions.

Over the last 50 years, there has been a steady reduction in the biodiversity of vegetables and other crops due to monoculture ${ }^{4}$. New varieties have been bred for increased yield, better appearance, and tolerance to pests and diseases, with little emphasis given to their resilience to major abiotic stresses such as drought and salinity. Such an approach reduces the number of cultivars upon which our global food security depends and does not consider the need for a broad genetic pool, which is needed to develop new varieties resilient to abiotic stresses imposed by climatic change. Solanaceae is a family of major crops, from which at least 15 genera are grown to provide food worldwide ${ }^{4}$. In 2010, 28 million hectares of solanaceous food crops were cultivated globally, producing around 540 million tons of potatoes, tomatoes, eggplants, and Capsicum spp. combined ${ }^{4}$. Extensive differences in salt tolerance have been reported among Solanaceae species. Huckleberry (Solanum scabrum Mill.) total leaf dry weight and leaf area were reduced by the application of $50 \mathrm{mM} \mathrm{NaCl}$ in 25 and $18 \%$ while these reductions were 47 and 55\% in eggplant (Solanum melongena L.), respectively ${ }^{5}$. The biomass and leaf area reductions were attributed to greater Na concentration in eggplant leaves as compared to huckleberry. Solanaceae is a large

${ }^{1}$ USDA-ARS, U.S. Salinity Lab, 450 W Big Springs Road, Riverside, CA 92507, USA. ${ }^{2}$ College of Natural and Agricultural Sciences, University of California Riverside, 900 University Avenue, Riverside, CA 92521, USA. ${ }^{\boxplus}$ email: devinder.sandhu@usda.gov 
tropical family with members characterized by their relative sensitivity to salinity ${ }^{6}$. Losses in fruit yield start at EC values of the soil saturation extract $\left(E_{\mathrm{e}}\right)$ of $1.1 \mathrm{dS} \mathrm{m}^{-1}$ for eggplant, $2.5 \mathrm{dS} \mathrm{m}^{-1}$ for tomato, and $1.5 \mathrm{dS} \mathrm{m}^{-1}$ for pepper ${ }^{6}$. The percent-fruit-yield decline per unit increase in salinity $\left(\mathrm{EC}_{\mathrm{e}}\right)$ was reported at $6.9,9.9$, and 14 for eggplant, tomato, and pepper, respectively ${ }^{6}$. These results suggest that at higher salinity, eggplant exhibits greater salt tolerance than tomato. However, eggplant and tomato had comparable decreases in vegetative yield under salinity of $3.7 \mathrm{dS} \mathrm{m}^{-1}$ when 'Black Bell' eggplant and 'Ikram' tomato plants were grafted onto two tomato rootstocks ${ }^{7}$. The reported salt-tolerance values for several crop species were often based on a relatively small number of studies (sometimes just one) where soil salinity was characterized and several salt levels were applied. However, cultivar differences, in general, were not reported in these databases.

It is well known that cultivar differences provide significant genetic variation for crop improvement ${ }^{8}$. The evaluation of four eggplant cultivars under irrigation water $\mathrm{EC}\left(\mathrm{EC}_{\mathrm{iw}}\right)$ ranging from 1.2 to $5.2 \mathrm{dS} \mathrm{m}^{-1}$ showed large differences in shoot biomass accumulation and for the quantum yield of photosystem II between salt-tolerant and salt-sensitive cultivars ${ }^{9}$. After 25 days under $\mathrm{EC}_{\mathrm{iw}}=5.2 \mathrm{dS} \mathrm{m}^{-1}$, fresh biomass decreased by $87 \%$ and $88 \%$ in 'Adriatica' and 'Black Beauty', respectively. In contrast, under the same salinity, fresh biomass decrease was only $37 \%$ and $36 \%$ for 'Bonica' and 'Galine', respectively'. The salt-tolerance threshold level (the level at which yield first starts to decrease) was different for fruit yield and shoot biomass in eggplant ${ }^{10,11}$. The threshold was between $\mathrm{EC}_{\mathrm{e}}=1.1$ and $1.5 \mathrm{dS} \mathrm{m}^{-1}$ for fruit yield ${ }^{10}$, whereas it was $6.7 \mathrm{dS} \mathrm{m}^{-1}$ for shoot biomass ${ }^{11}$. In a study with two eggplant cultivars, 'Bemisal' produced greater fresh weight than 'Dilnasheen', but both cultivars had approximately $50 \%$ reduction in fruit yield under $100 \mathrm{mM} \mathrm{NaCl}\left(\mathrm{EC}_{\mathrm{iw}} \text { of } 10 \mathrm{dS} \mathrm{m} \mathrm{m}^{-1}\right)^{12}$. Sensitivity to $\mathrm{Na}$ was attributed to the inability of eggplant to restrict $\mathrm{Na}$ uptake and transport to the leaf ${ }^{12}$. The literature is rich in papers dealing with strategies to mitigate salinity stress in eggplant, but we could not find many publications evaluating different cultivars for fruit yield under field conditions.

Tomato plants have been classified as 'moderately sensitive' to salinity, tolerating $\mathrm{EC}_{\mathrm{e}}=2.5 \mathrm{dS} \mathrm{m}^{-1}$ without fruit yield reduction ${ }^{6}$. However, in a two-year experiment in California, tomato fresh fruit yield was not significantly reduced when irrigated with $\mathrm{EC}_{\mathrm{iw}}=8.1 \mathrm{dS} \mathrm{m} \mathrm{m}^{-113}$. Greenhouse-cultivated tomato plants irrigated with $\mathrm{EC}_{\mathrm{iw}}=7.5 \mathrm{dS} \mathrm{m} \mathrm{m}^{-1}$ (moderate salinity) grew significantly better when pre-conditioned with a saline solution of $10 \mathrm{mM} \mathrm{NaCl}\left(\mathrm{EC}_{\mathrm{iw}} \sim 1.0 \mathrm{dS} \mathrm{m}^{-1}\right)^{14}$. In another study, the salt tolerance differences among tomato (Solanum lycopersicum $\mathrm{L}$.) cultivars were directly correlated with their $\mathrm{K}^{+}$and $\mathrm{Ca}^{2+}$ absorption ${ }^{15}$. Thus, it seems that tomato soil salinity threshold varies according to the cultivar used, and breeding of salt-tolerant cultivars will require exploring different mechanisms that play important roles during salinity stress ${ }^{16}$.

Pepper cultivation may differ from that of tomato and eggplant as the objective is not always the production of large, sweet fruits. Peppers are also cultivated to produce fruits with a pungency (heat in peppers provided by capsaicin alkaloids) for culinary purposes or even for their potential use as a source of capsaicin and dihydrocapsaicin as raw materials for topical anti-inflammatory and anti-rheumatoid arthritis medicines ${ }^{17,18}$.

A recent study reported differences in salt tolerance of two pepper cultivars under salinities ranging from 0 to $120 \mathrm{mM} \mathrm{NaCl}^{19}$. These authors reported that the superior salt tolerance of 'Quadrato D'Asti' pepper plants, compared to 'Cazzone Giallo', was due to their more efficient exclusion of $\mathrm{Cl}$ from shoots (leaves + stems). The accumulation of $\mathrm{Na}$ in both cultivars was 7.6 ('Quadrato D'Asti') to 12.5-fold ('Cazzone Giallo') smaller than $\mathrm{Cl}^{19}$. The authors did not discriminate $\mathrm{Na}$ or $\mathrm{Cl}$ accumulation between roots and shoots but, judging from the small accumulation of $\mathrm{Na}$ in shoots of both cultivars (11-12 $\mathrm{mg} \mathrm{kg}^{-1}$ at $120 \mathrm{mM} \mathrm{NaCl}$ ), most Na must have been retained by roots. Interestingly, although both cultivars accumulated similar concentrations of both $\mathrm{Na}$ and $\mathrm{Cl}$ in shoots at $30 \mathrm{mM} \mathrm{NaCl}$, 'Quadrado D'Asti' had no fruit yield decrease at that salt concentration ${ }^{19}$. The greatest significant fruit yield loss was reported in plants irrigated with the $\mathrm{NaCl}$ solution, followed by $\mathrm{KCl}$, and the lowest loss with the $\mathrm{K}_{2} \mathrm{SO}_{4}$ solution, probably due to the accumulation of $\mathrm{Cl}$, not $\mathrm{Na}$, in shoots ${ }^{20}$. Pepper salt tolerance was improved by grafting pepper plants onto rootstocks that restricted both $\mathrm{Na}$ and $\mathrm{Cl}$ transport to shoots and improved ion selectivity, such as preferred accumulation of K versus $\mathrm{Na}$ in shoots ${ }^{21}$.

Studies evaluating the relative importance of $\mathrm{Na}$ or $\mathrm{Cl}$, especially in vegetable plants, are limited. In both tomato ${ }^{22}$ and eggplant ${ }^{23}$, there was no significant difference in yield between salt solutions dominant in $\mathrm{Cl}^{-}$or $\mathrm{SO}_{4}{ }^{2-}$, suggesting that $\mathrm{Na}^{+}$is the dominant toxic ion for these species. This conclusion was confirmed by predicting eggplant yield of two different salt-tolerant cultivars, based on leaf $\mathrm{Na}$ concentration, but not with leaf Cl concentration ${ }^{23}$.

Effective comparison of crop salt tolerance among studies is difficult as experimental protocols do not have standardized parameters, the experiments rarely include the same cultivars, and do not contain enough (or the same) salt levels to allow for interexperiment comparisons. Among these experimental parameters are different temperatures, with plants under cooler temperatures exhibiting greater salt tolerance ${ }^{24}$; the salt composition of saline solutions ${ }^{25}$; outdoor versus greenhouse conditions, compounding of abiotic stresses such as drought and salinity ${ }^{26}$; differences in developmental stages ${ }^{27}$ and differences in plant organ yield (vegetative biomass versus fruit yield ${ }^{11}$. Another difficulty in comparing results among studies involves the reporting of soil extract salinity $\left(\mathrm{EC}_{\mathrm{e}}\right)$ or irrigation water salinity $\left(\mathrm{EC}_{\mathrm{iw}}\right)$. The latter is difficult to convert to $\mathrm{EC}_{\mathrm{e}}$ unless the leaching fraction or water budget data, including irrigation volumes, is available.

Heirloom cultivars have been grown for over 50 years and are appreciated for their unique appearance, flavor, cultural and ethnic significance, and their role in sustainable food production by small-scale farmers ${ }^{28}$. These authors also remarked on the urgent need to explore heirloom cultivars for their yield, organoleptic characteristics, and stress tolerance. The large genetic pool provided by heirloom cultivars for tolerance to abiotic stresses should assist in the development of more salt-tolerant vegetables.

Several genes involved in salinity response are known in plants $\mathrm{s}^{29,30}$. Transporter proteins are critical in regulating $\mathrm{Na}$ and $\mathrm{Cl}$ concentrations in plants, and various genes involved in these processes have been characterized ${ }^{29,31}$. Some studies have focused on identifying salt tolerance genes in Solanaceae. The differences in relative salt tolerance of two pepper cultivars were characterized by the more salt-tolerant cultivar having slightly increased 
$\mathrm{K} / \mathrm{Na}$ shoot ratio, decreased $\mathrm{K} / \mathrm{Na}$ root ratio, thus greater $\mathrm{K}$ leaf/root ratio and lower $\mathrm{Na}$ leaf/root ratio ${ }^{32}$. The enhanced performance of the salt-tolerant pepper cultivar was explained by the upregulation (or overexpression) of $A K T 1, K A T 1$, and SOS1 genes in the leaves. Similarly, overexpression of SISOS2 in transgenic tomato resulted in enhanced salt tolerance due to $\mathrm{Na}^{+}$exclusion from roots ${ }^{33}$. The superior salt tolerance of huckleberry as compared to eggplant was attributed to greater overexpression of $S s H K T$ in huckleberry compared to eggplant under salt stress ${ }^{34}$. Silencing the CaSBP12 gene in chili pepper (C. annuum. L.) increased salt tolerance measured from vegetative biomass and decreased shoot $\mathrm{Na}^{35}$. Similarly, silencing the SINAC11 gene reduced salinity and drought tolerance of tomato as evidenced by germination rate, chlorophyll content, and malondialdehyde (MDA) content $^{36}$. Despite some studies on salinity tolerance, the understanding of genetic networks involved in salinity tolerance is still limited in Solanaceae. Understanding different genetic factors involved in salinity stress will be critical in developing salt-tolerant genotypes in Solanaceae.

Our objectives were to (1) examine the salt tolerance of 23 Solanaceae cultivars (eight eggplant, seven tomato, and eight pepper) from different geographic regions, expressed as relative fruit yield over the life cycle of the plant under field conditions, (2) study the relationship between fruit yield and tissue ion composition, and (3) recognize genetic components regulating salinity tolerance in the Solanaceae family. Previous studies of Solanaceae salt tolerance have examined the relation of germination and shoot growth to gene expression for a few genotypes. In our attempt to maximize salt tolerance variability with commercially relevant genotypes, we selected only heirloom cultivars of three species from a worldwide range of geographic locations and climates.

\section{Results}

Fruit yields in response to salinity. Eggplant (Solanum melongena L.). Under control irrigation water $\left(\mathrm{EC}_{\mathrm{iw}}=0.65 \mathrm{dS} \mathrm{m} \mathrm{m}^{-1}\right)$, the highest cumulative fruit yield per plant was recorded for 'Black Beauty' (7624 g), and the lowest for 'Turkish Orange' (1627 g) (Fig. 1a). Under salinity conditions $\left(\mathrm{EC}_{\mathrm{iw}}=4.0 \mathrm{dS} \mathrm{m}^{-1}\right)$, 'Black Beauty' (3950 g) was also the highest fruit-yielding cultivar, significantly outproducing all other cultivars, while 'Turkish Orange' (1753 g) and 'Ping Tung' (1968 g) were the lowest (Fig. 1a).

The relative yield of the marketable part of the plant (yield under saline treatment/yield under control) is the commonly used criterion for evaluating salt tolerance ${ }^{6}$. Based on relative fruit yield data, 'Black Beauty' and 'Kazakhstan' were salt-sensitive, with a relative yield of $52 \%$ and $68 \%$ when exposed to salinity (Fig. $1 \mathrm{~b}$ ), while 'Long Purple' (114\%) and 'Turkish Orange' (108\%) were the most salt-tolerant cultivars with no cumulative fruit yield loss under saline treatment (Fig. 1b).

Tomato (Solanum lycopersicum L.). Under control conditions, cumulative fruit yield was significantly greater for 'Bloody Butcher' (2785 g), 'Jaune Flamme' (2317 g), and 'Thessaloniki' (1,712 g), with 'Bloody Butcher' having the greatest cumulative yield and 'Quarter Century' (1415 g) the lowest (Fig. 1c). The remaining cultivars produced significantly lower cumulative fruit yields than 'Bloody Butcher', but there were no significant differences among them (Fig. 1c). Under saline conditions, 'Quarter Century' had the lowest cumulative yield (928 g), and 'Bloody Butcher' (1719 g) the highest. Although 'Jaune Flamme' produced a heavier crop than both 'Red Pear' and 'Yellow Pear' under control conditions, these three cultivars had similar fruit yields under salinity (Fig. 1c). The greatest relative yield was for 'Red Pear' (84\%), closely followed by 'Yellow Pear' (82\%), then 'Garden delight' (75\%) while the lowest relative yield (56\%) was for 'Jaune Flamme' (Fig. 1d).

Pepper (Capsicum spp.). Under control conditions, the highest cumulative fruit yield was achieved by 'California Wonder' (2951 g), which was significantly greater than all other cultivars, followed by 'Costa Rican' (2545 g), 'Ajvarski' (2318 g), 'Corbaci' similar to 'Jimmy Nardello,' 'Orange Habanero', and 'Thai Hot' (Fig. 1e). The lowest yield was for 'Thai Hot' ( $291 \mathrm{~g}$ ), which produced numerous red peppers of very small size, and maintained its cumulative fruit yield under salinity (Fig. 1e). Under saline conditions, the significantly greatest cumulative yield was also for 'California Wonder' (1932 g), followed by 'Costa Rican' (1597 g), 'Ajvarski' (1353 g) similar to 'Ancho' (1335 g), 'Jimmy Nardello' (989 g) similar to 'Corbaci' (866 g), and 'Orange Habanero' pepper (369 g) similar to 'Thai Hot' (290 g) (Fig. 1e).

The highest relative yield was for 'Thai Hot' (100\%) as it had no yield loss, followed by 'Ancho' (85\%) (Fig. 1f). The other cultivars had relative fruit yields ranging from $52 \%$ ('Cobaci') to $65 \%$ ('California Wonder').

Tissue ion concentrations in response to salinity. Eggplant. This species showed significant increases in leaf $\mathrm{Na}$ concentration between control and salt treatments for all cultivars, except for 'Black Beauty' (Fig. 2a). There were also significant differences among cultivars. Under saline conditions, 'Turkish Orange' ( $\left.30 \mathrm{mmol} \mathrm{kg}^{-1}\right)$ accumulated the most $\mathrm{Na}$ in the leaves, followed by 'Long Purple' $\left(17.7 \mathrm{mmol} \mathrm{kg}^{-1}\right)$, and 'Tadifi' $\left(8.5 \mathrm{mmol} \mathrm{kg}^{-1}\right)$. 'Black Beauty' accumulated the least concentration of $\mathrm{Na}\left(2.4 \mathrm{mmol} \mathrm{kg}{ }^{-1}\right)$ in the leaves, followed by 'Kazakhstan' ( $3.5 \mathrm{mmol} \mathrm{kg} \mathrm{m}^{-1}$ ) and 'Ping Tung' $\left(4.3 \mathrm{mmol} \mathrm{kg} \mathrm{m}^{-1}\right.$ (Fig. 2a). In terms of increase relative to the control, 'Turkish Orange' had a $2070 \% \mathrm{Na}$ increase in the leaves, 'Long Purple' a $198 \%$ increase, and 'Black Beauty' a 31\% increase (Fig. 2a). 'Turkish Orange' accumulated significantly more Na in the roots $\left(439 \mathrm{mmol} \mathrm{kg}^{-1}\right.$ ) than all other cultivars under the saline treatment (Fig. 2b).

The $\mathrm{Cl}$ leaf concentration data showed no significant differences among varieties under control conditions, with concentrations ranging from $377 \mathrm{mmol} \mathrm{kg}^{-1}$ for 'Ping Tung' to $507 \mathrm{mmol} \mathrm{kg}^{-1}$ for 'Long Purple' (Fig. 2c). However, most varieties had increases in leaf $\mathrm{Cl}$ under the saline treatment with significant differences in leaf $\mathrm{Cl}$ among cultivars (Fig. 2c). 'Kazakhstan' (721 mmol kg-1), 'Tadifi' (706 mmol kg-1), and 'Turkish Orange' $\left(692 \mathrm{mmol} \mathrm{kg}^{-1}\right)$ accumulated the most $\mathrm{Cl}$ in their leaves. 'Black Beauty' (475 mmol kg-1) accumulated the least amount of $\mathrm{Cl}$ in the leaves, followed by 'Bangladeshi Long' (548 mmol kg-1) (Fig. 2c). 'Black Beauty' showed only a slight increase in leaf $\mathrm{Cl}$ under salt treatment $(475 \mathrm{mmol} \mathrm{kg}-1)$ as compared to control $\left(443 \mathrm{mmol} \mathrm{kg}^{-1}\right)$. 

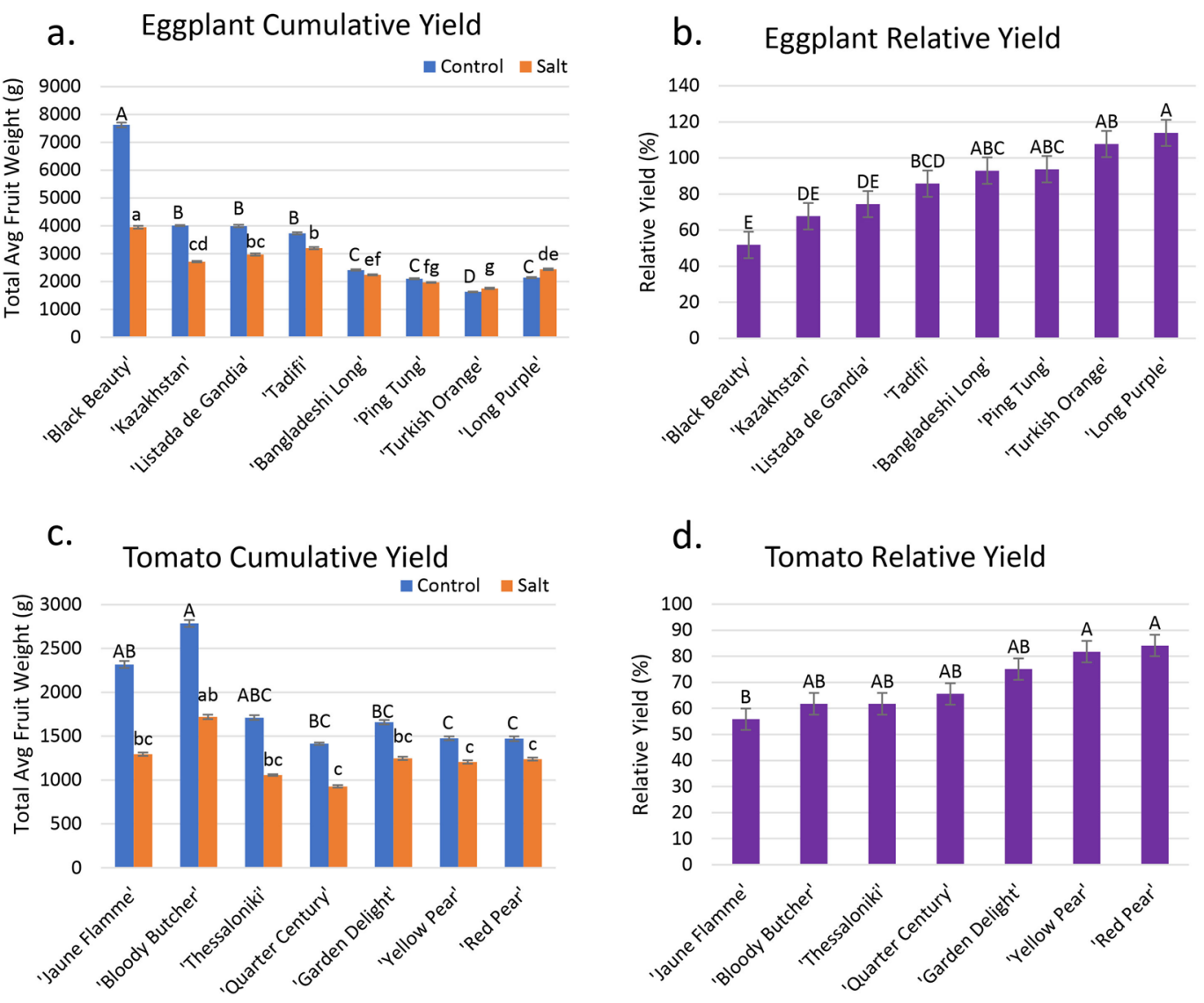

\section{d. Tomato Relative Yield}

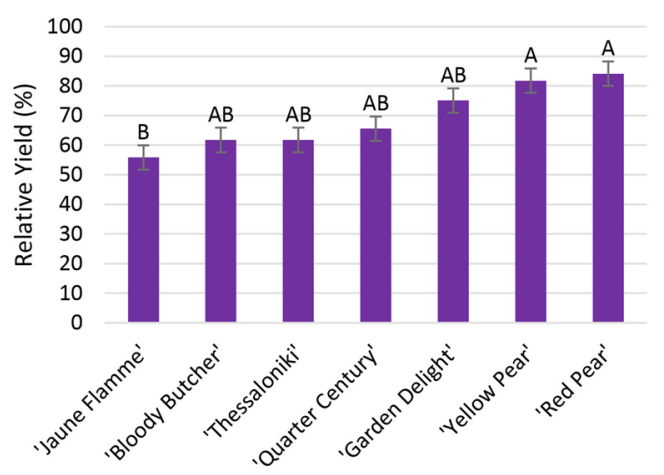

e.

$$
\text { f. }
$$
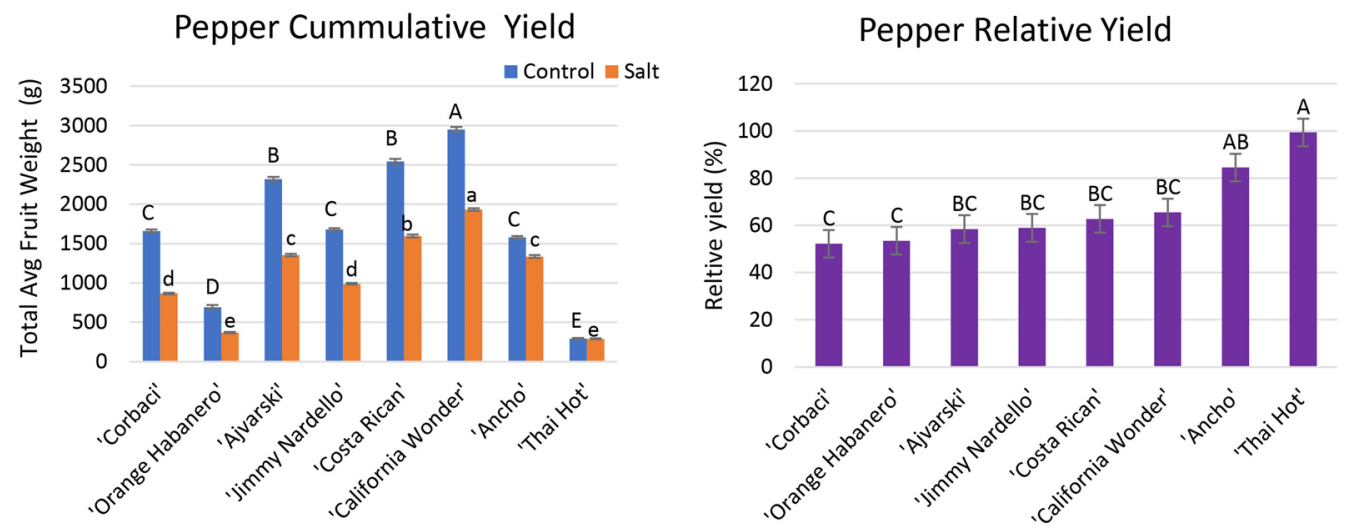

Figure 1. Fruit yield of eggplant, tomato, and pepper under control and saline irrigation waters. (a) Cumulative fresh weight fruit yield for 8 eggplant cultivars. (b) Relative yield (yield of saline treatment/yield of control) for 8 eggplant cultivars, expressed as a percent. (c) Cumulative fresh weight fruit yield for 7 tomato cultivars. (d) Relative yield for 7 tomato cultivars, expressed as a percent. (e) Cumulative fresh weight fruit yield for 8 pepper cultivars. (f) Relative yield for 8 pepper cultivars, expressed as a percent. Capital letters denote significant differences in yield under control conditions, while lowercase letters denote significant yield differences under saline conditions $(p<0.05)$. Error bars represent standard errors.

'Turkish Orange' accumulated significantly more $\mathrm{Cl}\left(453 \mathrm{mmol} \mathrm{kg}{ }^{-1}\right)$ in the roots than all other cultivars under salt treatment (Fig. 2d).

There were significant differences in K concentrations both between treatments and among cultivars, but no significant interaction between treatments and cultivars (Fig. 2e). Under control conditions, there were no

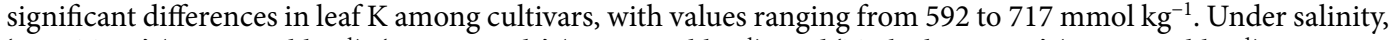
'Ping Tung' (932 mmol kg-1), 'Long Purple' ( $887 \mathrm{mmol} \mathrm{kg}^{-1}$ ), and 'Turkish Orange' (794 mmol kg $\left.{ }^{-1}\right)$, accumulated the most $\mathrm{K}$ in the leaves. 'Kazakhstan' $\left(537 \mathrm{mmol} \mathrm{kg}^{-1}\right)$ and 'Black Beauty' $\left(625 \mathrm{mmol} \mathrm{kg}^{-1}\right)$ accumulated 


\section{a.}

Leaf $\mathrm{Na}$

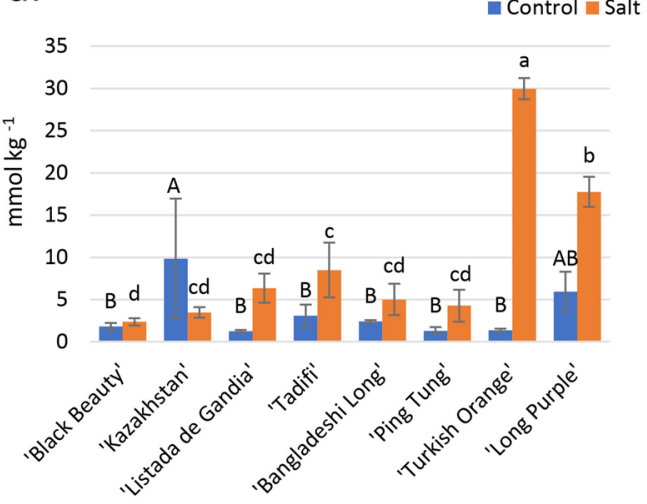

C.

Eggplant

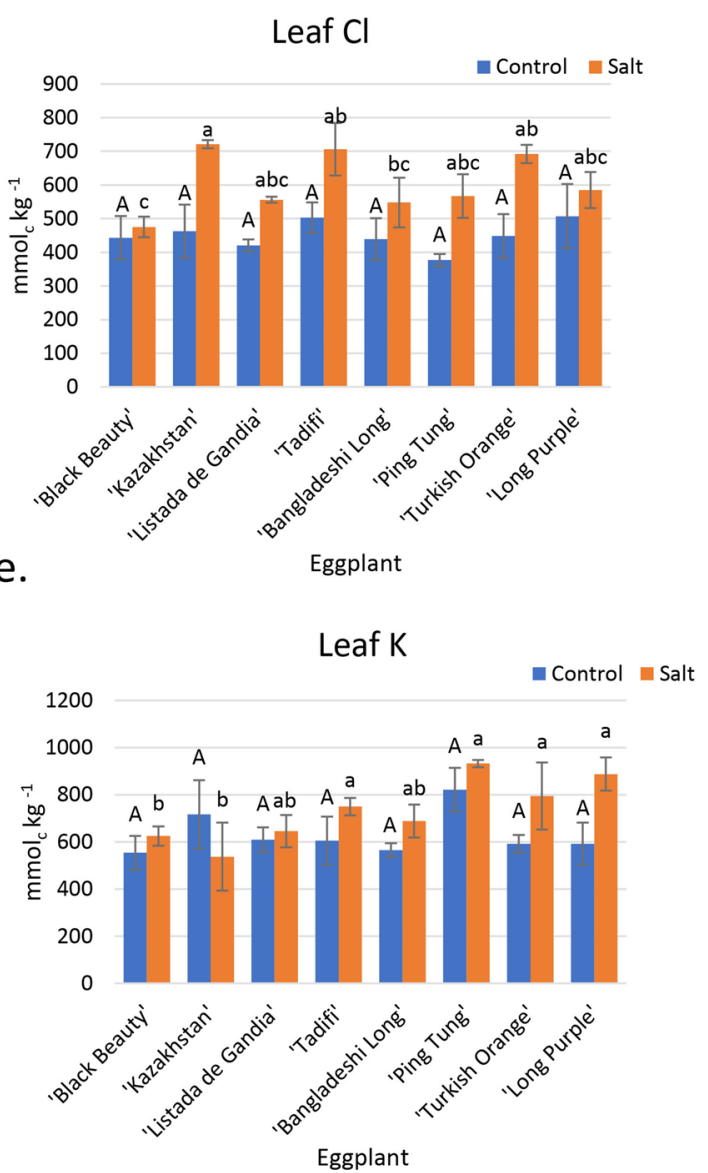

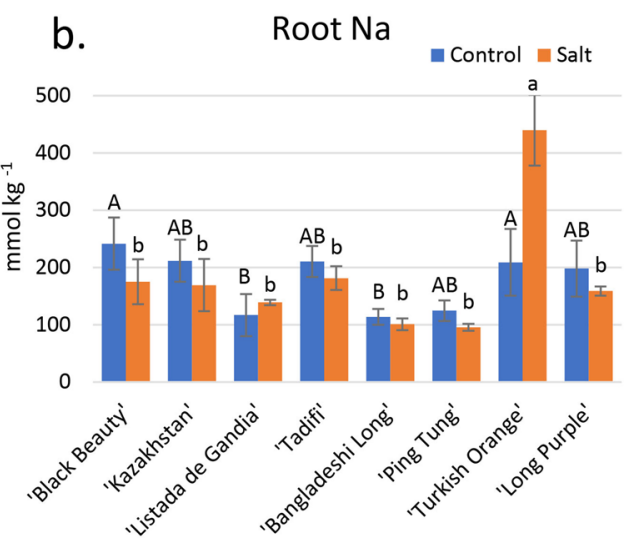

d.

Eggplant

Root $\mathrm{Cl}$

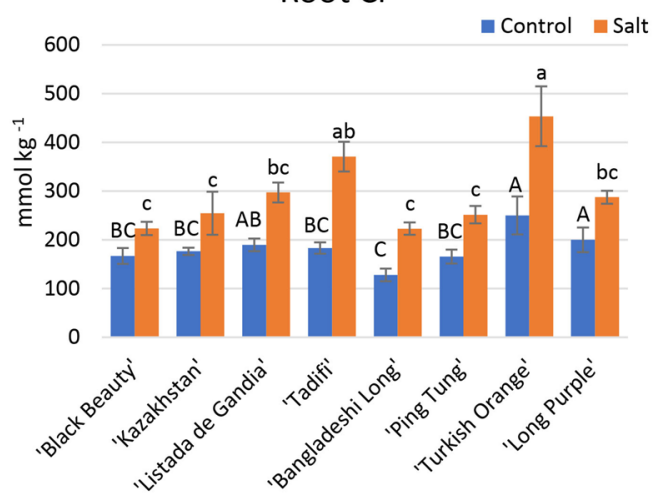

f.

Eggplant

Root K

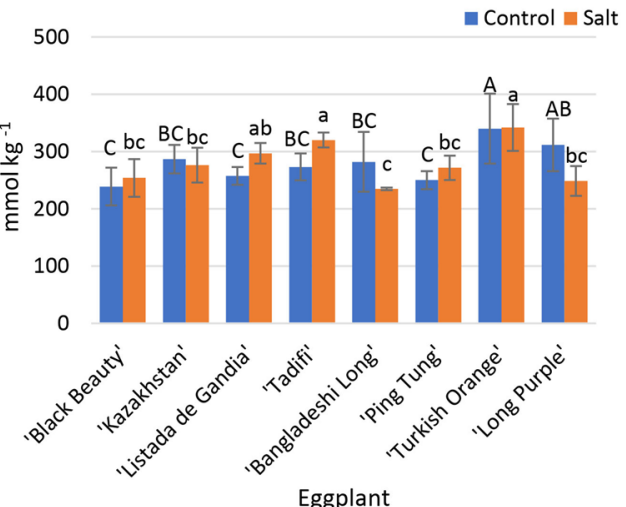

Figure 2. Tissue ion concentrations of eight eggplant cultivars irrigated with control and saline irrigation waters. (a) Leaf Na concentrations. (b) Root Na concentrations. (c) Leaf Cl concentrations. (d) Root Cl concentrations. (e) Leaf K concentrations. (f) Root K concentrations. Capital letters denote differences among cultivars under control conditions, while lowercase letters denote significant differences under saline conditions $(p<0.05)$. Error bars represent standard errors.

the least amount of $\mathrm{K}$ in their leaves (Fig. 2e). Under salinity, 'Turkish Orange' (342 $\mathrm{mmol} \mathrm{kg}{ }^{-1}$ ) and 'Tadifi' $\left(320 \mathrm{mmol} \mathrm{kg}{ }^{-1}\right)$ accumulated significantly more $\mathrm{K}$ in the roots than all other cultivars, and 'Bangladeshi Long' $\left(235 \mathrm{mmol} \mathrm{kg}{ }^{-1}\right)$ accumulated the least $\mathrm{K}$ under the salt treatment (Fig. 2f). Eggplant cultivars varied significantly in their relative leaf $\mathrm{K}$ concentration under salinity compared to control (K-salinity/K-control). The two most salt-tolerant cultivars of eggplant, 'Long Purple' and 'Turkish Orange', had leaf K-salinity/K-control ratios of 1.43 and 1.37, respectively ( $\mathrm{K}$ data in Fig. 2e). However, even the two most salt-sensitive varieties, 'Black Beauty' and 'Kazakhstan', had K-salinity/K-control ratios of 0.98 each.

There were no significant differences in leaf $\mathrm{Ca}$ concentration among treatments or for the interaction between $\mathrm{Ca}$ and salinity, although there were significant differences among cultivars (Supplementary Fig. S1a). 'Ping Tung' 
(590 mmol kg-1) accumulated the most $\mathrm{Ca}$ in the roots under control, significantly greater than all, except for 'Bangladeshi Long' (507 mmol kg${ }^{-1}$ ). Under salinity, 'Bangladeshi Long' (474 mmol kg-1) had the greatest Ca concentration, along with 'Ping Tung' ( $469 \mathrm{mmol} \mathrm{kg}^{-1}$ ), significantly greater Ca for all but one cultivar ('Tadifi') $\left(426 \mathrm{mmol} \mathrm{kg}{ }^{-1}\right)$, while Black Beauty' $\left(220 \mathrm{mmol} \mathrm{kg}{ }^{-1}\right)$ and 'Turkish Orange' $\left(242 \mathrm{mmol} \mathrm{kg}{ }^{-1}\right)$ had the least Ca concentrations (Supplementary Fig. S1b).

There were no significant differences in leaf $\mathrm{Mg}$ concentrations among cultivars under control conditions (Supplementary Fig. S2a). Leaf Mg increased under saline treatment for all cultivars except 'Long Purple'. Under salinity, 'Turkish Orange' (356 mmol kg-1) and 'Tadifi' (354 mmol kg-1) accumulated the most $\mathrm{Mg}$ in the leaves while 'Long Purple' (232 $\mathrm{mmol} \mathrm{kg}^{-1}$ ) accumulated the least amount, significantly less than 'Turkish Orange' (Supplementary Fig. S2a). 'Turkish Orange' (198 mmol kg-1) accumulated significantly more $\mathrm{Mg}$ in the roots than the other varieties under both control and salinity conditions (Supplementary Fig. S2b).

There were no significant differences in leaf nitrogen concentration between salinity treatments or between the interaction of the two, but there were significant differences among cultivars. Under salinity, 'Turkish Orange' (4\%) and 'Kazakhstan' (3\%) accumulated the most nitrogen in the leaves (Supplementary Fig. S3a).

Tomato. Under control conditions, 'Bloody Butcher' accumulated significantly more $\mathrm{Na}\left(156 \mathrm{mmol} \mathrm{kg}^{-1}\right)$ in its leaves than all other cultivars, followed by 'Quarter Century' $\left(90 \mathrm{mmol} \mathrm{kg}{ }^{-1}\right)$ and 'Yellow Pear' $\left(90 \mathrm{mmol} \mathrm{kg}^{-1}\right)$ (Fig. 3a). 'Garden Delight' accumulated the least amount of $\mathrm{Na}\left(60 \mathrm{mmol} \mathrm{kg}{ }^{-1}\right)$ in the leaves, significantly less than the three highest $\mathrm{Na}$ accumulators. Under saline conditions, 'Bloody Butcher' $\left(334 \mathrm{mmol} \mathrm{kg}^{-1}\right)$, followed by 'Jaune Flamme' (331 mmol kg-1) accumulated the most leaf $\mathrm{Na}$, while 'Red Pear' $\left(145 \mathrm{mmol} \mathrm{kg}^{-1}\right)$ accumulated the lowest concentration of $\mathrm{Na}$, followed by 'Quarter Century' $\left(165 \mathrm{mmol} \mathrm{kg}{ }^{-1}\right)$. Compared to other cultivars, 'Jaune Flamme' accumulated the most $\mathrm{Na}$ in the roots under both control $\left(375 \mathrm{mmol} \mathrm{kg}^{-1}\right)$ and saline (540 mmol kg-1) conditions (Fig. 3b).

Under control conditions, 'Bloody Butcher' $\left(464 \mathrm{mmol} \mathrm{kg}^{-1}\right)$ accumulated the most $\mathrm{Cl}$, significantly greater than the lowest accumulators, 'Yellow Pear' (245 mmol kg-1) 'Quarter 'Thessaloniki' (250 mmol kg-1), and Century' (280 mmol kg-1), (Fig. 3c). Under salinity, 'Jaune Flamme' (777 mmol kg-1) accumulated the most $\mathrm{Cl}$ in the leaves, followed by 'Garden Delight' $\left(657 \mathrm{mmol} \mathrm{kg}^{-1}\right)$. 'Thessaloniki' (468 $\mathrm{mmol} \mathrm{kg}^{-1}$ ) accumulated the least amount of $\mathrm{Cl}$ in the leaves, significantly less than the top $\mathrm{Cl}$ accumulators (Fig. 3c). However, under salinity, 'Thessaloniki' ( $\left.618 \mathrm{mmol} \mathrm{kg}{ }^{-1}\right)$ was the top root $\mathrm{Cl}$ accumulator, and 'Yellow Pear' $\left(453 \mathrm{mmol} \mathrm{kg}^{-1}\right)$ was the least $\mathrm{Cl}$ accumulator (Fig. 3d).

'Quarter Century' (730 mmol kg-1) accumulated significantly more $\mathrm{K}$ in the leaves than all other cultivars except 'Bloody Butcher' ( $573 \mathrm{mmol} \mathrm{kg}{ }^{-1}$ ) and 'Thessaloniki' (556 $\mathrm{mmol} \mathrm{kg}^{-1}$ ) under control conditions (Fig. 3e). Under saline conditions, K decreased for all cultivars, but 'Quarter Century' ( $575 \mathrm{mmol} \mathrm{kg}^{-1}$ ) had significantly greater $\mathrm{K}$ than all other cultivars, and 'Jaune Flamme' $\left(299 \mathrm{mmol} \mathrm{kg}{ }^{-1}\right)$ accumulated the least amount of $\mathrm{K}$, significantly less than all cultivars except 'Garden Delight' $\left(339 \mathrm{mmol} \mathrm{kg}{ }^{-1}\right.$ ) and 'Yellow Pear' (342 $\mathrm{mmol} \mathrm{kg}^{-1}$ ) (Fig. 3e). 'Thessaloniki' (387 $\mathrm{mmol} \mathrm{kg}^{-1}$ ) was the top K accumulator in roots under salinity, and 'Yellow Pear' (250 mmol kg-1) was the least $\mathrm{K}$ accumulator (Fig. 3f). 'Red Pear' and 'Yellow Pear' (the two most salt-tolerant cultivars) had K-salinity/K-control ratios of 0.85 each, and 'Jaune Flamme' and 'Bloody Butcher' (the two most salt-sensitive cultivars) had K-salinity/K-control ratios of 0.68 and 0.75 , respectively (K data in Fig. 3e).

Leaf concentrations of Ca were significantly greater in 'Garden Delight' $\left(1,110 \mathrm{mmol} \mathrm{kg}{ }^{-1}\right)$ and 'Red Pear' (980 mmol kg-1) as compared to 'Thessaloniki' $\left(652 \mathrm{mmol} \mathrm{kg}{ }^{-1}\right)$ and 'Quarter Century' $\left(691 \mathrm{mmol} \mathrm{kg}^{-1}\right)$ under control conditions. Under salt conditions, 'Garden Delight' ( $933 \mathrm{mmol} \mathrm{kg}^{-1}$ ) accumulated significantly more Ca in the leaves than 'Yellow Pear' (733 mmol kg-1), 'Red Pear' (692 mmol kg-1), 'Quarter Century' $\left(643 \mathrm{mmol} \mathrm{kg}^{-1}\right)$, and 'Thessaloniki' (619 mmol kg-1) (Supplementary Fig. S1c). 'Red Pear' (512 mmol kg-1) accumulated significantly more $\mathrm{Ca}$ in the roots than 'Yellow Pear' $\left(339 \mathrm{mmol} \mathrm{kg}{ }^{-1}\right)$ under saline treatment (Supplementary Fig. S1d).

Under control conditions, 'Red Pear' ( $346 \mathrm{mmol} \mathrm{kg}{ }^{-1}$ ) had the greatest leaf Mg concentrations, significantly different than the lowest accumulator, 'Thessaloniki' ( $\left.230 \mathrm{mmol} \mathrm{kg}{ }^{-1}\right)$, while under saline conditions, 'Red Pear' $\left(418 \mathrm{mmol} \mathrm{kg}^{-1}\right)$, 'Yellow Pear' (394 mmol kg-1) and 'Garden Delight' (389 $\mathrm{mmol} \mathrm{kg}^{-1}$ ) had significantly greater $\mathrm{Mg}$ than 'Thessaloniki' ( $280 \mathrm{mmol} \mathrm{kg}^{-1}$ ) (Supplementary Fig S2c). The Mg concentration was greater in the salt treatment than in the control. 'Red Pear' ( $\left.192 \mathrm{mmol} \mathrm{kg}^{-1}\right)$ accumulated significantly more $\mathrm{Mg}$ in the roots than 'Bloody Butcher' (118 mmol kg-1) and 'Quarter Century' $\left(120 \mathrm{mmol} \mathrm{kg}^{-1}\right)$ under the saline treatment (Supplementary Fig S2d).

There were no significant differences in N leaf concentration under control, but 'Red Pear' (4\%), 'Yellow Pear'(3\%), and 'Jaune Flamme' (3\%) accumulated significantly more N in the leaves than 'Quarter Century' (2.6\%) under saline conditions (Supplementary Fig. S3c).

Pepper. The leaf Na data for peppers showed significant differences among different cultivars under control conditions. 'Orange Habanero' plants $\left(138 \mathrm{mmol} \mathrm{kg}{ }^{-1}\right)$ had the highest leaf-Na concentration among all peppers under control conditions, with all the others averaging $12.5 \mathrm{mmol} \mathrm{kg}{ }^{-1}$. Under salinity, 'Orange Habanero' $\left(558 \mathrm{mmol} \mathrm{kg}{ }^{-1}\right)$ had significantly greater Na than all others (Fig. 4a). 'Thai Hot' accumulated the second-highest $\mathrm{Na}$ concentration $(22 \mathrm{mmol} \mathrm{kg}$ ) in leaves under salinity-although still over 25 times lower than 'Orange Habanero'; yet, it had the greatest relative yield. 'Ajvarski' $\left(329 \mathrm{mmol} \mathrm{kg}^{-1}\right)$ accumulated the most $\mathrm{Na}$ in the roots under salinity (Fig. 4b).

Under control conditions, 'Orange Habanero' $\left(241 \mathrm{mmol} \mathrm{kg}^{-1}\right)$ accumulated the most $\mathrm{Cl}$, significantly greater than all other cultivars, which averaged $131 \mathrm{mmol} \mathrm{kg}^{-1}$ (Fig. 4c). Under saline conditions, leaf $\mathrm{Cl}$ increased greatly in all cultivars with 'Orange Habanero' plants $\left(915 \mathrm{mmol} \mathrm{kg}{ }^{-1}\right)$, 'Ancho' $\left(841 \mathrm{mmol} \mathrm{kg}^{-1}\right)$, and 'Corbaci' (791 $\mathrm{mmol} \mathrm{kg}^{-1}$ ) having the highest $\mathrm{Cl}$ leaf accumulation (although not significantly from 'Jimmy Nardello' and 'Costa Rican'), and 'Thai Hot' (501 $\mathrm{mmol} \mathrm{kg}^{-1}$ ) had the lowest Cl accumulation. 'Corbaci' (344 mmol kg-1) 

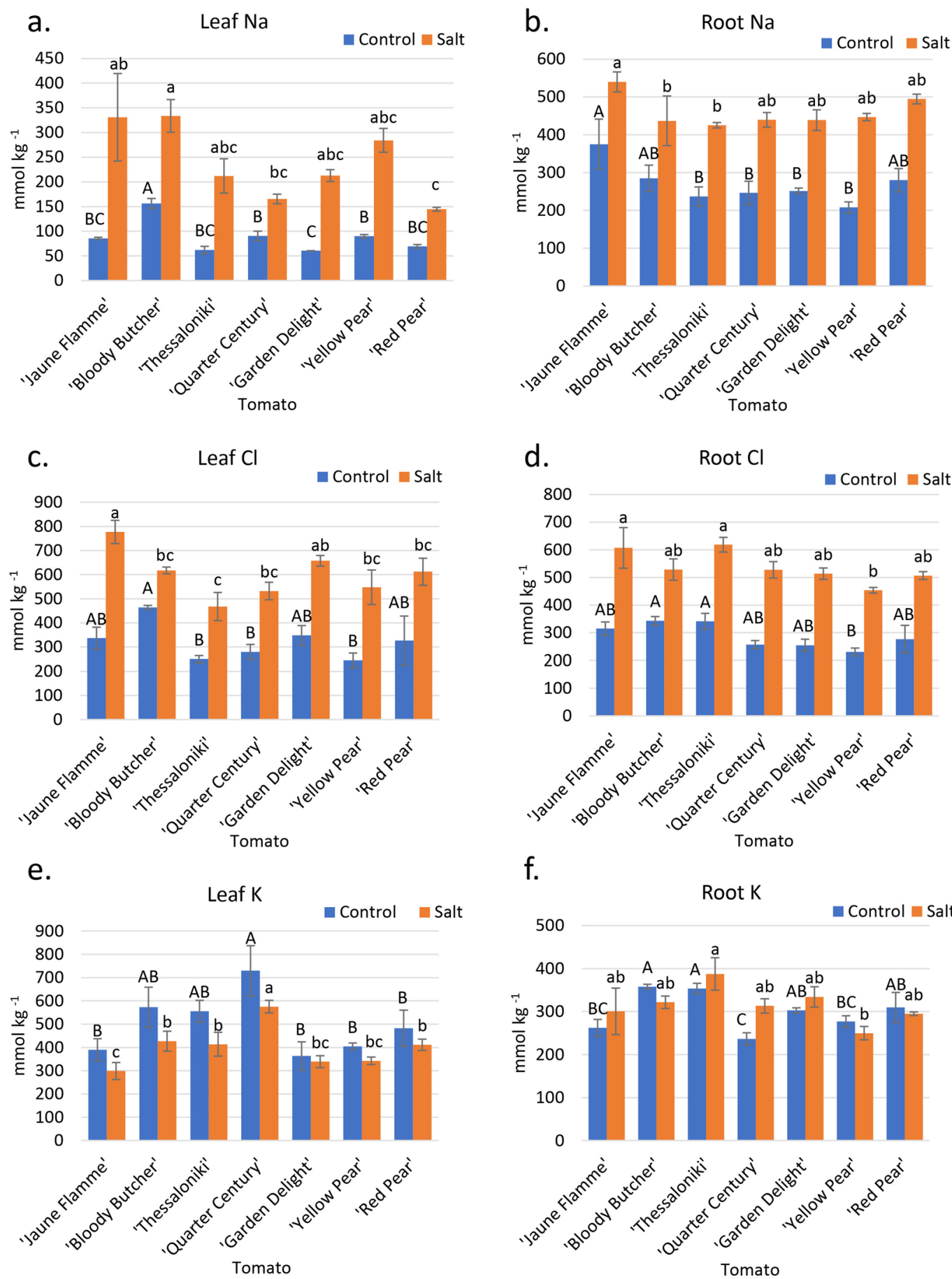

f.
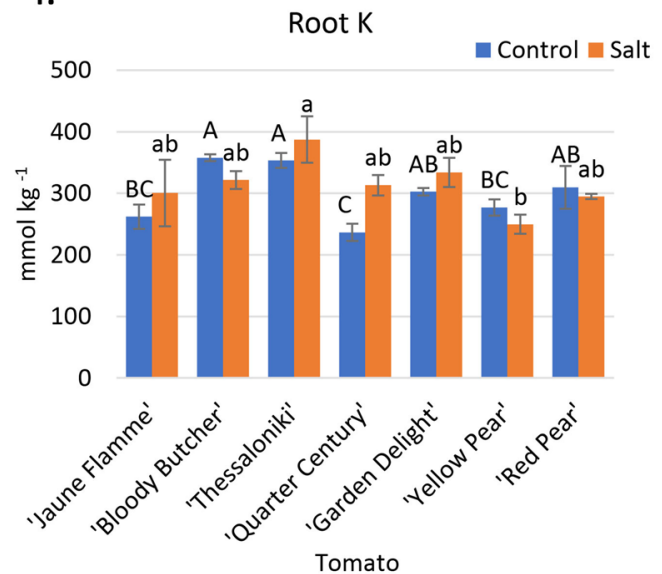

Figure 3. Tissue ion concentrations of seven tomato cultivars irrigated with control and saline irrigation waters. (a) Leaf Na concentrations. (b) Root Na concentrations. (c) Leaf Cl concentrations. (d) Root Cl concentrations. (e) Leaf K concentrations. (f) Root $\mathrm{K}$ concentrations. Capital letters denote differences among cultivars under control conditions, while lowercase letters denote significant differences under saline conditions $(p<0.05)$. Error bars represent standard errors.

accumulated significantly more $\mathrm{Cl}$ in the roots than 'Costa Rican' (212 $\mathrm{mmol} \mathrm{kg}^{-1}$ ) and 'Orange Habanero' $\left(238 \mathrm{mmol} \mathrm{kg}^{-1}\right)$ in the saline treatment (Fig. $\left.4 \mathrm{~d}\right)$.

'California Wonder' $\left(1,053 \mathrm{mmol} \mathrm{kg}{ }^{-1}\right)$ accumulated the most $\mathrm{K}$ in the leaves under control conditions, followed by 'Ajvarski' (995 mmol kg-1), 'Corbaci' $\left(990 \mathrm{mmol} \mathrm{kg}{ }^{-1}\right)$, 'Jimmy Nardello' $\left(977 \mathrm{mmol} \mathrm{kg}^{-1}\right.$ ), and 'Costa Rican' (914 mmol kg-1), while 'Orange Habanero' plants $\left(639 \mathrm{mmol} \mathrm{kg}^{-1}\right)$ accumulated the least $\mathrm{K}$ (Fig. 4e). Under saline conditions, similar rankings occurred, except that 'Jimmy Nardello' $\left(1000 \mathrm{mmol} \mathrm{kg}^{-1}\right)$ had the highest K content, although not significantly higher than 'Ajvarski', 'Costa Rican', 'California Wonder' and 'Corbaci' (Fig. 4e). 

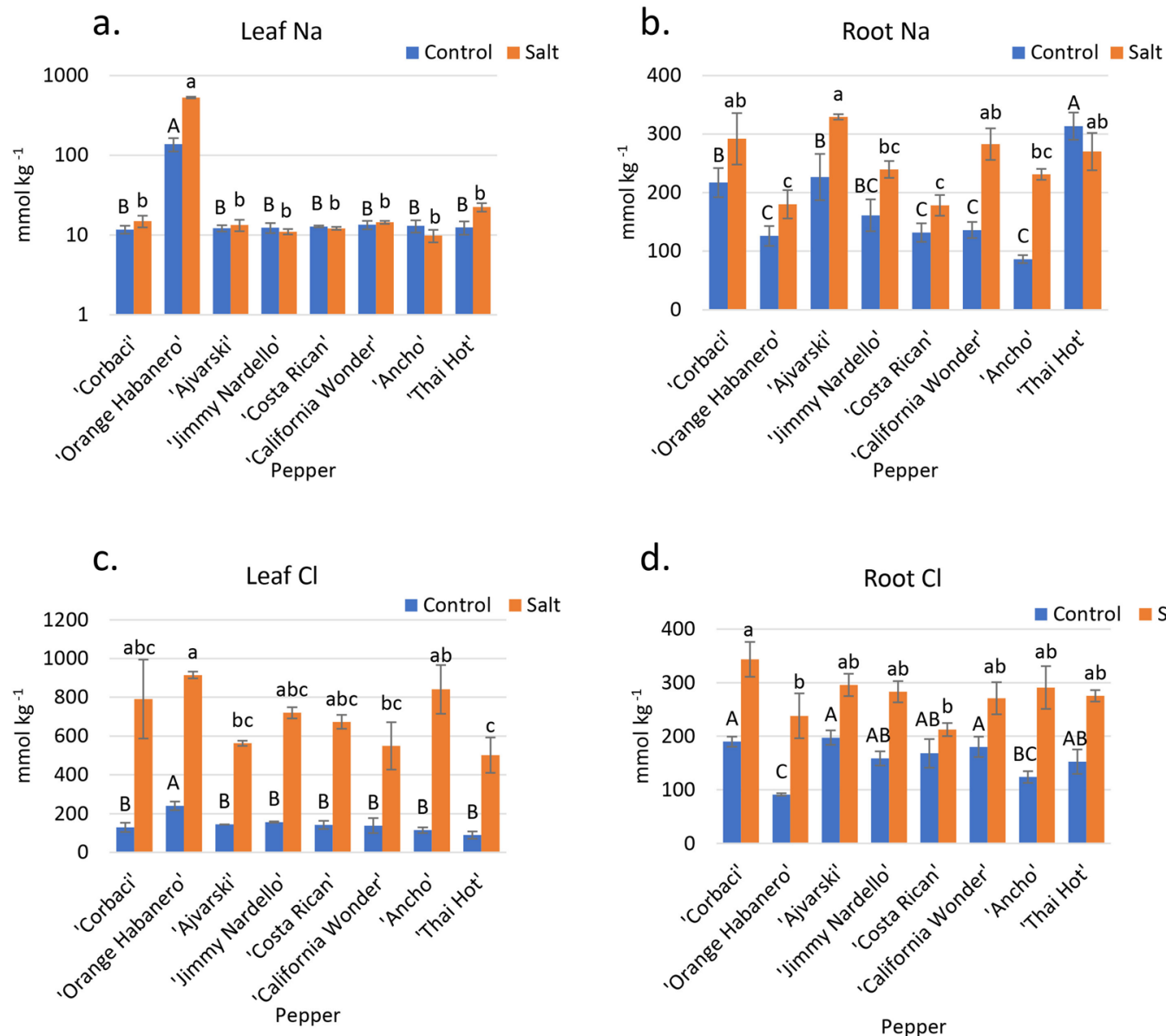

d.
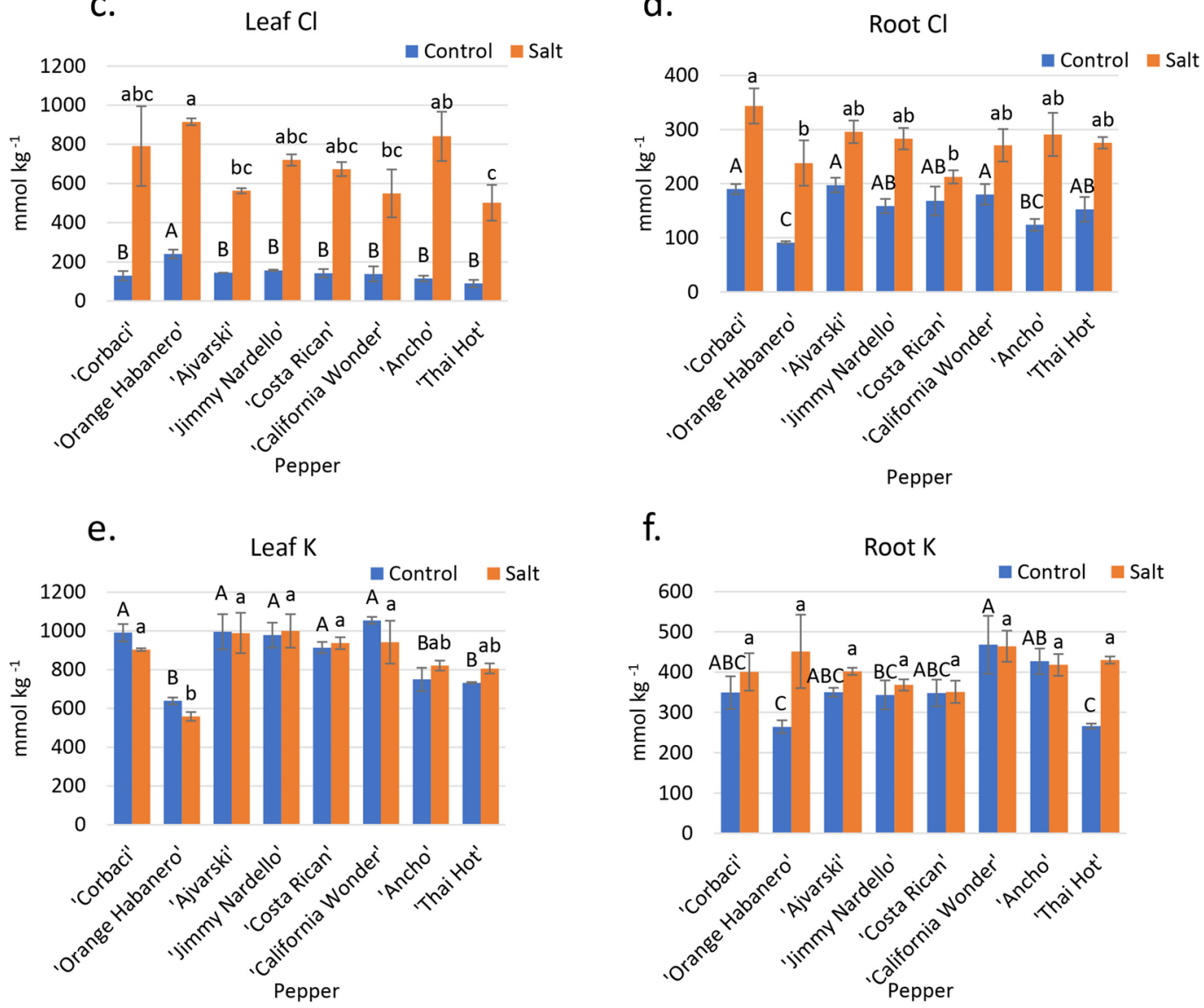

Figure 4. Tissue ion concentrations of eight pepper cultivars irrigated with control and saline irrigation waters. (a) Leaf Na concentrations. (b) Root Na concentrations. (c) Leaf Cl concentrations. (d) Root Cl concentrations. (e) Leaf $\mathrm{K}$ concentrations. (f) Root $\mathrm{K}$ concentrations. Capital letters denote differences among cultivars under control conditions, while lowercase letters denote significant differences under saline conditions $(p<0.05)$. Error bars represent standard errors.

In roots, under salinity, there was no significant difference among cultivars in K concentrations (Fig. 4f). Two salt-tolerant cultivars, 'Thai Hot' and 'Ancho', maintained high K-salinity/K-control ratios of 1.10 each, and two salt-sensitive cultivars, 'Corbaci' and 'Bloody Butcher', had K-salinity/K-control ratios of 0.91 and 0.87 , respectively ( $\mathrm{K}$ data in Fig. 4e).

'Corbaci' accumulated significantly more $\mathrm{Ca}$ and $\mathrm{Mg}$ in the leaves than 'Costa Rican' and 'Orange Habanero' plants under both control and saline conditions (Supp Fig. S1e and S2e). 'Thai Hot' (552 $\mathrm{mmol} \mathrm{kg}^{-1}$ ) accumulated significantly more $\mathrm{Ca}$ in the roots than all other cultivars under control conditions and significantly more Ca than 'Jimmy Nardello' (169 mmol kg ${ }^{-1}$ ) under salinity (Supp Fig. S1f). 'Corbaci' (181 mmol kg-1) accumulated the greatest amount of $\mathrm{Mg}$ in roots under the control condition, followed by 'Jimmy Nardello' (157 $\mathrm{mmol} \mathrm{kg}^{-1}$ ) 
and 'California Wonder' $\left(145 \mathrm{mmol} \mathrm{kg}{ }^{-1}\right)$, while under the saline treatment, 'California Wonder' (128 $\left.\mathrm{mmol} \mathrm{kg}^{-1}\right)$ had the greatest Mg concentration, significantly more than 'Costa Rican'( $\left.84 \mathrm{mmol} \mathrm{kg}^{-1}\right)$ (Supp. Fig. S2f).

'California Wonder' (5\%) had significantly greater $\mathrm{N}$ in leaves under the control treatment. However, there was no significant difference in leaf- $\mathrm{N}$ accumulation in the cultivars under salinity (Supp. Fig. S3c).

Effect of salinity on gene expression. For expression analyses, one salt-tolerant and one salt-sensitive genotype were selected each for eggplant, tomato, and pepper, based on their cumulative yield, relative yield, and ion uptake. The selected genotypes were 'Long Purple' (tolerant) and 'Kazakhstan' (sensitive) for eggplant, 'Red Pear' (tolerant) and 'Bloody Butcher' (sensitive) for tomato, and 'Ancho' (tolerant) and 'Corbaci' (sensitive) for pepper. A set of 12 genes known to be involved in salinity stress in model plants was used to study gene expression changes under control and salinity in three Solanaceae crops (Supplementary Table S1). The selected genes included $\mathrm{Na}^{+}$transporters (AKT1, AVP1, NHX1, NHX2, SOS1, SOS2, and SOS3) and $\mathrm{Cl}^{-}$transporters (ALMT9, $C C C, C L C c, C L C g$, and SLAH3).

The expression analyses showed that most genes were upregulated in roots under salinity compared to control for tomato and pepper (Fig. 6). However, eggplant roots did not show general upregulation under salinity. The overall expression of tested genes in pepper and eggplant was relatively low in leaves compared to roots (Fig. 6). This pattern was not consistent in tomato.

Of the genes involved in $\mathrm{Na}^{+}$transport, $A K T 1$, SOS2, and SOS3 were significantly upregulated in roots under salinity compared to control in 'Long Purple', a relatively salt-tolerant cultivar of eggplant (Fig. 6). None of the $\mathrm{Na}^{+}$ transporter genes were differentially expressed in the roots of the salt-sensitive cultivar 'Kazakhstan'. In leaves of 'Long Purple' (salt-tolerant cultivar), AKT1 was upregulated under salinity compared to control, whereas SOS1, SOS2, and SOS3 were upregulated under salinity compared to control in 'Kazakhstan' (Fig. 6).

In tomato, AVP1, NHX1, NHX2 were upregulated in the roots of 'Red Pear' (salt-tolerant) under salinity (Fig. 6). Interestingly, $A K T 1, A V P 1, S O S 1, S O S 2$, and $S O S 3$ were upregulated in roots of the salt-sensitive 'Bloody Butcher' under salinity.

In pepper, three $\mathrm{Na}^{+}$transporter genes (AKT1, SOS1, SOS3) were upregulated in roots of both 'Ancho' (salttolerant) and 'Corbaci' (salt-sensitive) under salinity (Fig. 6). SOS2, however, was upregulated in 'Ancho' roots but downregulated in 'Corbaci'. In leaves of 'Corbaci', AKT1 and NHX1 were downregulated under salinity compared to control. On the other hand, for 'Ancho', none of the $\mathrm{Na}^{+}$transporter genes were differentially expressed in leaves under salinity or control (Fig. 6).

The $\mathrm{Cl}^{-}$transporter genes, $C L C c$ and $C L C g$ were upregulated, and $A L M T 9$ was downregulated under salinity compared to control in roots of salt-tolerant 'Long Purple' cultivar of eggplant (Fig. 6). CLCg and SLAH3 were downregulated under salinity compared to control in leaves of 'Long Purple'. None of the $\mathrm{Cl}^{-}$transporters genes were differentially expressed in roots or leaves of 'Kazakhstan' (Fig. 6).

In tomato, $C C C, C L C c$, and $C L C g$ were upregulated in roots of both 'Red Pear' and 'Blood Butcher' under salinity compared to control (Fig. 6). However, ALMT9 and SLAH3 were upregulated only in 'Red Pear' roots. Three $\mathrm{Cl}^{-}$transporter genes, $A L M T 9, C C C$, and $C L C c$ were significantly downregulated in leaves of the saltsensitive 'Blood Butcher' under salinity compared to control (Fig. 6).

In pepper, $C L C g$ and $S L A H 3$ were upregulated in roots of both 'Ancho' (salt-tolerant) and 'Corbaci' (saltsensitive) (Fig. 6). In addition, $A L M T 9$ and $C L C g$ were upregulated only in 'Corbaci' roots. In 'Corbaci' leaves, $A L M T 9$ was upregulated, whereas $C L C g$ was downregulated under salinity compared to control (Fig. 6). SLAH3 was upregulated in both leaves and roots of 'Ancho' and 'Corbaci'.

In the roots of salt-tolerant genotypes, there was a greater expression of some genes under control than for salt-sensitive genotypes for all three species. For instance, in eggplant, SOS1, SOS2, ALTM9, and CCC genes had at least twofold greater expression in 'Long Purple' roots under control than in 'Kazakhstan' under control (Fig. 6). Similarly, for tomato, SOS1, SOS2, and CLCc had at least double the expression levels in 'Red Pear' roots compared to 'Bloody Butcher' under control. For pepper, 'Ancho' roots showed more than two-fold expressions for NHX1 and CLCc compared to 'Corbaci' under control (Fig. 6).

\section{Discussion}

This study attempted to identify and characterize salinity tolerance mechanisms in three Solanaceae crops: eggplant, tomato, and pepper. We used eight, seven, and eight different heirloom cultivars for eggplant, tomato, and pepper, respectively, and evaluated their salinity tolerance by irrigating the plants with control $\left(\mathrm{EC}_{\mathrm{iw}}=0.65 \mathrm{dS} \mathrm{m}{ }^{-1}\right)$ or saline water $\left(\mathrm{EC}_{\mathrm{iw}}=4.0 \mathrm{dS} \mathrm{m} \mathrm{m}^{-1}\right)$.

All species showed a significant reduction in fruit yield under salinity compared to control. The ratio of fruit yield under salinity divided by that under control is defined as the Salinity Tolerance Index (STI) and ranged from 0.52 to $1.14,0.56$ to 0.84 , and 0.52 to 0.99 for eggplant, tomato, and pepper, respectively (Fig. 1 ). When averaged over all the cultivars tested in each species, eggplant showed the highest STI (0.86), followed by tomato (0.69), and then pepper (0.67) (Fig. 1). Thus, eggplant had better tolerance to salinity than tomato and pepper. Our data demonstrated large variability in cultivar salt tolerance and a difference in relative ranking as compared to the ranking in a widely cited review of crop salt tolerance where at $\mathrm{EC}_{\mathrm{e}}=4 \mathrm{dS} \mathrm{m} \mathrm{m}^{-1}$ the STI values were $0.80,0.85$, and 0.75 for eggplant, tomato, and pepper, respectively ${ }^{6}$. However, in this review crop salt tolerance was based on only 1-2 studies of each species, where salinity was well characterized and multiple salinity levels were tested. In addition, the greater eggplant salt tolerance that we report can be explained by the association of eggplant cultivars with their putative wild ancestor Solanum insanum, which showed higher tolerance to salinity than the domesticated Solanum melongena when both species were submitted to salinities ranging from 0 to $300 \mathrm{mM} \mathrm{NaCl}$ for 25 days $^{37}$. This illustrates that vegetables have been primarily selected for yield and appearance 
and not for tolerance to abiotic stresses such as salinity, but such genes can still be found in wild cultivars and maybe heirloom cultivars.

The two top salt-tolerant eggplant cultivars were 'Long Purple' and 'Turkish Orange', and the two most salt-sensitive cultivars were 'Black Beauty' and 'Kazakhstan' (Fig. 1b). For tomato, 'Red Pear' and 'Yellow Pear' outperformed other cultivars in relative yield, and 'Jaune Flamme' and 'Bloody Butcher' were the worst performers (Fig. 1d). 'Thai Hot' and 'Ancho' cultivars of pepper were the most salt-tolerant, while 'Corbaci' and 'Orange Habanero' were the most salt-sensitive (Fig. 1f).

Previous research suggests that the ability of a plant to manage $\mathrm{Na}, \mathrm{Cl}$, and $\mathrm{K}$ during salinity stress is critical for its ability to tolerate salinity ${ }^{22,23,38}$. After evaluating these cultivars under the hot field climatic conditions of southern California for their whole crop cycle, it is reasonable to assume that, for the cultivars reported here as salt-sensitive, salt effects were related to ion toxicity rather than osmotic stress. Also, our relatively low salt stress $\left(\mathrm{EC}_{\mathrm{iw}}=4 \mathrm{dS} \mathrm{m} \mathrm{m}^{-1}\right)$, corresponds to roughly- $0.16 \mathrm{MPa}$ of osmotic pressure, too low to create water stress. In our experiment, all three Solanaceae crops had high Na concentrations in roots compared to leaves (Figs. 2a,b, 3a,b and $4 \mathrm{a}, \mathrm{b}$ ), with the notable exception of 'Orange Habanero' plants, suggesting that there is a distinct mechanism regulating translocation of $\mathrm{Na}$ from roots to shoots. Total leaf concentrations of $\mathrm{Na}$ were drastically different in all three Solanaceae crops tested. Except for 'Orange Habanero', pepper and eggplant had less than tenfold leaf $\mathrm{Na}$ accumulation compared to tomato (Figs. 2a, 3a, and 4a). These observations indicate that eggplant and pepper plants have a more efficient mechanism to regulate the translocation of $\mathrm{Na}$ from roots to shoots.

Considering the market value of hot peppers for their international culinary appreciation and the pharmacological and commercial value of capsaicin and dihydrocapsaicin, 'Thai Hot' (C. annuum L.) and 'Orange Habanero' pepper (C. chinense Jacq.) were included as representatives of hot peppers. 'Thai Hot' was the most salt-tolerant of all the pepper species having no decrease in fruit yield or size under salinity (Fig. 1e), whereas 'Orange Habanero' was one of the most salt-sensitive pepper cultivars (Fig. 1f). 'Orange Habanero' has a medium size for a hot pepper and is much larger than 'Thai Hot', but its hollow fruit and its thin flesh compared to other peppers (e.g., 'Ancho') account for its low fruit yield, even under control conditions. 'Orange Habanero' is a very aromatic pepper favored by its mild heat ${ }^{39}$, attractive orange color, aroma when ripe, and long shelf life, making it one of the most commonly found hot peppers in supermarkets and fresh market stands.

Among peppers, only 'Orange Habanero' showed a high accumulation of $\mathrm{Na}$ in leaves $\left(527.8 \mathrm{mmol} \mathrm{kg}^{-1}\right)$ under salinity; all the other cultivars accumulated between 9.8 and $22.4 \mathrm{mmol} \mathrm{kg}^{-1}$ (Fig. 4a). 'Orange Habanero' had more than 23-fold difference in leaf $\mathrm{Na}$ accumulation compared to the rest of the pepper cultivars, indicating that the specific difference in $\mathrm{Na}$ translocation from roots to shoots of this species (Capsicum chinense) may reflect the possible center of origin of 'Orange Habanero' compared to the other pepper plants belonging to the species C. annuum. 'Orange Habanero' ancestors seem to have originated from tropical climates from Central and South America, such as Brazil, Peru, and Surinam, and the Pacific Islands, such as Hawaii, Fiji, Samoa, Guam, etc. $^{40,41}$ and later on spread throughout the New World into places of similar climates, such as Florida, St. Augustine, and Puerto Rico ${ }^{41}$. This striking difference in the control of $\mathrm{Na}^{+}$transport from roots to shoots is typical of glycophyte plants that originated and evolved in areas where $\mathrm{Na}^{+}$was not a selective pressure in the evolution of the species. This hypothesis is consistent with the fact that soils of the Amazonian basin have very low available $\mathrm{Na}$ and $\mathrm{Ca}^{42}$. On the other hand, the greatest diversity of cultivated forms of C. annuum were reported to have originated mainly from Central Mexico with a secondary center in Guatemala ${ }^{41}$.

For several plant species, cultivars that efficiently exclude $\mathrm{Na}$ are the most salt-tolerant ${ }^{30}$. Our results showed that tomato and pepper followed these anticipations; however, eggplant data did not follow the expected trend. 'Bloody Butcher' and 'Jaune Flamme', two tomato cultivars with the lowest STI, accumulated the highest leaf Na under the salinity treatment (Fig. 3a). Conversely, 'Red Pear', the cultivar with the highest STI, accumulated the least amount of $\mathrm{Na}$ in the leaves under salinity. On the other hand, 'Red Pear' had a relatively high root Na concentration (Fig. 3b). The low Na leaf concentration of 'Red Pear' is thus likely related to its ability to restrict Na translocation from root to shoot rather than restrict Na uptake. For pepper, 'Orange Habanero', with the second lowest STI, had the greatest leaf accumulation of Na by far (Fig. 4a). In addition, 'Orange Habanero' had one of the lowest root $\mathrm{Na}$ concentrations, thus demonstrating its inability to restrict $\mathrm{Na}$ translocation from root to shoot (Fig. 4b) that again may be related to its evolution in tropical countries with soils poor in $\mathrm{Na}^{+}$. 'Corbaci', which had the lowest STI, was the third largest in leaf Na accumulation (Fig. 4a). 'Ancho', one of the best performing cultivars, had the lowest leaf $\mathrm{Na}$ concentration and has been recently reported, along with other C. annuum species, as one of the landraces that may have its center of origin in central to northern $\mathrm{Mexico}^{43}$, a region of relatively high soil salinity. Although leaf $\mathrm{Na}$ concentration showed association with salt tolerance of different cultivars, it was not always perfect. For instance, 'Thai Hot', a cultivar with the highest STI, accumulated a high amount of $\mathrm{Na}$ in leaves (Figs. If and $4 \mathrm{a}$ ). These observations suggest that different cultivars may vary in component traits of the salt tolerance mechanisms, emphasizing the complexity of the plant responses to salinity stress.

Similar to leaf $\mathrm{Na}$ concentration data, leaf $\mathrm{Cl}$ data showed some association with STI for tomato and pepper, but not for eggplant. In tomato, 'Red Pear' and 'Yellow Pear', two cultivars with high STI, had low leaf Cl concentrations (Fig. 3c). On the other hand, salt-sensitive cultivars, 'Jaune Flamme' and 'Bloody Butcher', had higher leaf $\mathrm{Cl}$ concentrations (Fig. 3c). For pepper, 'Corbaci' was the most salt-sensitive, had the highest leaf $\mathrm{Cl}$ concentration. In contrast, 'Thai Hot' that was the most salt-tolerant cultivar, had the lowest leaf Cl concentration (Fig. 3c). However, 'Ancho', one of the most salt-tolerant cultivars, also accumulated a high amount of $\mathrm{Cl}$ in leaves. These observations suggest that although leaf $\mathrm{Cl}$ concentration is an important parameter during salinity stress, the overall salinity tolerance of a cultivar is regulated by a complex of several factors.

Potassium is an important macronutrient in plants that is involved in several physiological and biochemical processes, including cell osmoticum, $\mathrm{pH}$ regulation, stomatal opening/closing, regulation of membrane potential, and enzyme activity ${ }^{44}$. As $\mathrm{Na}^{+}$competes with $\mathrm{K}^{+}$for binding sites, high salt negatively affects the $\mathrm{K}$ content in plants $^{45}$. Most plants show decreased leaf K concentration under salinity ${ }^{38,46}$; this includes tomato ${ }^{15,47-49}$, where 
yield loss in $\mathrm{NaCl}$ solution was attributed to $\mathrm{Na}$-induced $\mathrm{K}$ deficiency ${ }^{50}$. However, in tomato studies with multiple salinity levels, leaf K levels did not significantly decrease until large yield losses occurred ${ }^{11,22}$. In another tomato study with two species, the L. cheesmanii species from the Galapagos Islands showed less reduction in vegetative growth (more salt-tolerant ) than did L. esculentum Mill cv. VF 36, but the decrease in leaf K with salinity was more marked for the more salt-tolerant species L. cheesmanii ${ }^{51}$.

In our study, pepper cultivars showed no change in leaf $\mathrm{K}$ (Fig. 4e), but tomato cultivars showed an average of $21 \%$ decrease in leaf K concentration under salinity compared to control (Fig. 3e). Interestingly, eggplant cultivars showed an average of $19 \%$ increase in leaf $\mathrm{K}$ concentration under salinity than control (Fig. 3e). Tomato plants are considered to be deficient in $\mathrm{K}$ when mature leaf $\mathrm{K}$ concentrations are below $380 \mathrm{mmol}$ per $\mathrm{kg}^{52}$. Increasing $\mathrm{K}$ application in tomato from 200 to $400 \mathrm{mg} \mathrm{L}^{-1}$ under saline conditions $(35 \mathrm{mM} \mathrm{NaCl}$ ) resulted in increased leaf and root $\mathrm{K}$ and decreased leaf and root $\mathrm{Na}^{53}$. However, fruit yield was unaffected by $\mathrm{K}$ addition. With this criterion applied to other Solanaceae species, none of our eggplant or pepper cultivars were deficient in K (Figs. 2e and 4e). However, under salt stress, 'Jaune Flamme' tomato plants were deficient in $\mathrm{K}\left(300 \mathrm{mmol} \mathrm{kg}{ }^{-1}\right)$, and 'Garden Delight' and 'Yellow Pear' were borderline deficient (Fig. 3e). As 'Jaune Flamme 'had the most significant yield loss of all tomato cultivars (Fig. 1), it is reasonable to attribute this loss to K deficiency under salt treatment. Tomato shoot dry weight reduction of $20 \%$ was reported when leaf $\mathrm{K}$ was $250 \mathrm{mmol}$ per $\mathrm{kg}^{52}$.

Previous studies with pepper also show decreasing $\mathrm{K}$ with increasing salinity for whole plant ${ }^{54}$ as well as leaf $\mathrm{K}$ concentration ${ }^{21}$. Previous studies with eggplant generally showed decreasing K with increasing salinity ${ }^{55}$. However, a hydroponic study with 4 eggplant cultivars showed no significant changes in leaf $\mathrm{K}$ at 20 and $40 \mathrm{mM}$ $\mathrm{NaCl}$ treatments while vegetative fresh weight significantly decreased ${ }^{56}$. At the highest salt levels, the more saltsensitive cultivar (20\% relative biomass) experienced a greater decline in leaf $\mathrm{K}$ than the more salt-tolerant one $(65 \% \text { relative biomass })^{56}$.

As discussed above, eggplant showed relatively little $\mathrm{Na}$ accumulation in leaves as compared to tomato (Figs. 2a, 3a, and 4a). It is known that the exclusion of $\mathrm{Na}^{+}$from plant tissue leads to high $\mathrm{K}^{+}$levels ${ }^{57}$. Hence, the differences in relative leaf $\mathrm{K}$ concentration under salinity compared to control (K-salinity/K-control) among three Solanaceae crops may result from differences in exclusion of $\mathrm{Na}^{+}$from leaves.

We observed a strong association between salt tolerance and leaf K-salinity/K-control ratio for all Solanaceae species (Fig. 5). Cultivars with high STI also had a high K-salinity/K-control ratio in leaves. STI and K-salinity/Kcontrol ratio depicted high correlations with $\mathrm{R}^{2}$ values of $0.60,0.69$, and 0.59 for eggplant, tomato, and pepper, respectively (Fig. 5). Net leaf K concentration did not show an association with salinity tolerance. For instance, pepper cultivar 'Thai Hot' (most salt-tolerant) had a lower leaf K concentration under salinity compared to 'Corbaci' (most salt-sensitive) (Fig. 4e). Hence, our data suggest that rather than net K concentration in leaf, the K-salinity/K-control ratio is more critical in determining salinity tolerance of a genotype in Solanaceae. In a previous study, the main feature of the salt-tolerant cultivar of eggplant was shown to be its ability to absorb $\mathrm{K}^{+}$ by upregulation of several $\mathrm{K}$ transporter ${ }^{32}$. In an almond study focusing on characterizing salinity responses in 14 almond rootstocks, the percent reduction in leaf-K concentration under salinity was highly correlated with salinity tolerance ${ }^{38}$.

To understand the roles of different players involved in salinity stress, expression analyses were conducted for genes involved in $\mathrm{Na}^{+}$and $\mathrm{Cl}^{-}$transport using a salt-tolerant and a salt-sensitive cultivar for each of the three Solanaceae crops. The selected salt-tolerant and salt-sensitive cultivars include 'Long Purple' and 'Kazakhstan', 'Red Pear' and 'Bloody Butcher', and 'Ancho' and 'Corbaci', for eggplant, tomato, and pepper, respectively. The general expression levels of several genes were higher in roots compared to leaves in eggplant and pepper (Fig. 6). Given that most of the genes used in the study regulate $\mathrm{Na}^{+}$and $\mathrm{Cl}^{-}$transport, and that roots play an important role in the uptake and translocation of these ions, higher expression levels of these genes in roots would be expected. The low expression levels of genes involved in $\mathrm{Na}^{+}$transport in leaves of eggplant and pepper may also explain why $\mathrm{Na}$ concentration was more than tenfold lower in leaves of eggplant and pepper than tomato (Figs. 2a, 3a, and $4 \mathrm{a}$ ).

It has been observed in some plant species that the basic expression levels of several genes involved in salinity stress are higher in salt-tolerant genotypes compared to salt-sensitive genotypes ${ }^{38}$. Based on the genes tested in this investigation, we did not see that general trend (Fig. 6). However, CCC and SOS2 showed at least twofold expression in the roots of 'Long Purple' compared to 'Kazakhstan' eggplants, both under control and salinity, which may indicate that the basic expression levels of some genes may be critical in imparting salinity tolerance in salt-tolerant genotypes compared to the salt-sensitive ones (Fig. 6).

Several genes showed differential expression under salinity compared to control in Solanaceae species. In eggplant, three genes involved in $\mathrm{Na}^{+}$transport, AKT1, SOS2, and SOS3, were significantly induced under salinity in the roots of salt-tolerant cultivar Long Purple, while none of the genes involved in Na transport were induced in the salt-sensitive cultivar 'Kazakhstan' (Fig. 6). These observations demonstrate that 'Long Purple' is better equipped to tolerate salinity by excluding $\mathrm{Na}^{+}$from roots. Two genes involved in $\mathrm{Cl}^{-}$transport, $C L C c$, and $C L C g$, were induced under salinity compared to control in roots of 'Long Purple' but not in 'Kazakhstan', which may explain greater $\mathrm{Cl}$ concentration in 'Kazakhstan' leaves as compared to 'Long Purple'.

In tomato, three genes involved in sequestering $\mathrm{Na}^{+}$in the vacuole, $N H X 1, N H X 2$, were upregulated under salinity in roots of 'Red Pear' but not in 'Bloody Butcher', suggesting that 'Red Pear' may better partition excess $\mathrm{Na}^{+}$in the vacuole, protecting the cytoplasm from Na${ }^{+}$toxicity (Fig. 6). 'Red Pear's root Na concentration was higher than 'Bloody Butcher', but due to effective compartmentalization of $\mathrm{Na}^{+}$in the vacuole, the relative fruit yield performance of 'Red Pear' was better under salinity, making it salt-tolerant. Several important genes involved in $\mathrm{Na}^{+}$uptake SOS1, SOS2, and SOS3 were upregulated in salt-sensitive tomato cultivar 'Bloody Butcher' (Fig. 6), suggesting that the SOS pathway is active in 'Bloody Butcher', which is justified by its secondlowest root Na concentration among all tomato cultivars (Fig. 3b). However, 'Bloody Butcher' showed significant 

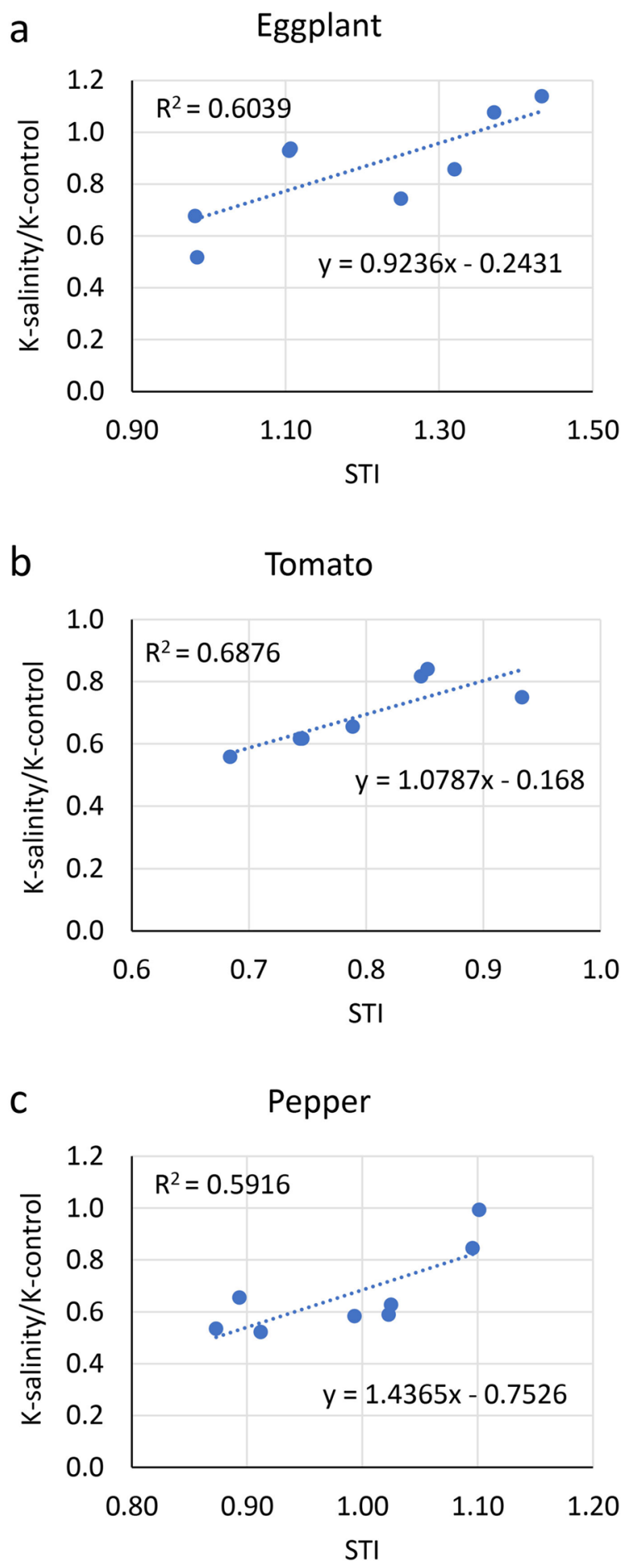

Figure 5. Relationship of the ratio of leaf $\mathrm{K}$ under salinity and control (K-salinity/K-control) with salt tolerance index (STI) in eggplant, tomato, and pepper. (a) Eggplant. (b) Tomato. (c) Pepper. Dots represent the mean values of different cultivars.

downregulation of three $\mathrm{Cl}^{-}$transporter genes, ALMT9, CCC, and CLCc, in leaves (Fig. 6), which may have contributed toward its salt-sensitivity compared to 'Red Pear'.

In pepper, most of the genes were upregulated both in roots of salt-tolerant ('Ancho') and salt-sensitive ('Corbaci') cultivars. However, SOS2 was upregulated in the roots of 'Ancho', but it was downregulated in the roots of 'Corbaci' (Fig. 6), which may be the reason for the better performance of 'Ancho' as compared to 'Corbaci' under salinity. 


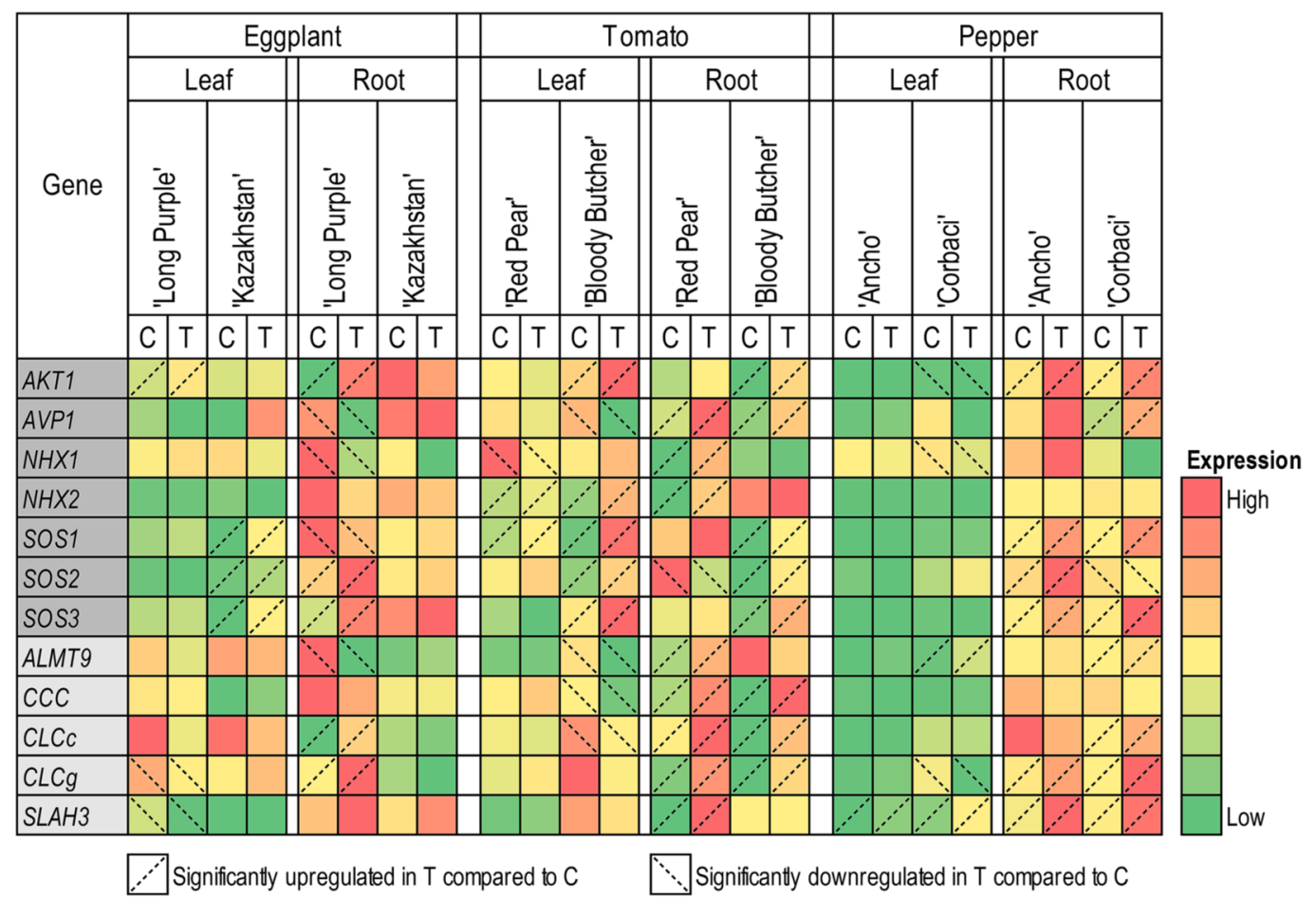

Figure 6. Heatmap representing the relative expression of salt stress-related genes in roots and leaves of a salt-tolerant and a salt-sensitive cultivar each of the three Solanaceae crops, eggplant, tomato, and pepper. Expression values for each gene are color-coded to depict the fold-change in different cultivars. The genes highlighted in dark gray represent genes involved in $\mathrm{Na}$ transport, and the genes highlighted in light green represent genes involved in $\mathrm{Cl}$ transport. $\mathrm{C}$, control; $\mathrm{T}$, salinity treatment.

\section{Conclusion}

Our selection of cultivars of heirloom vegetables based on different geographic regions produced expected, as well as less expected, results. In general, based on the salt tolerance index (STI), eggplant was the most salttolerant species $(\mathrm{STI}=0.86)$, followed by tomatoes $(\mathrm{STI}=0.69)$, and then peppers $(\mathrm{STI}=0.67)$, the most sensitive among the three crops.

Eggplant, a crop that originated in Asia and cultivated for centuries in Asia, Africa, Europe, and the Near East, has controversial accounts for its center of origin but is mostly cultivated in China, India, Egypt, Turkey, and $\operatorname{Japan}^{58}$. The cultivars 'Long Purple' (from India) and 'Turkish Orange' (from Turkey) demonstrated the highest tolerance to salinity as might be expected, but 'Ping Tung' (from Taiwan) and 'Bangladeshi Long' (from India) were close contenders and lost minimal fruit yield under salinity making eggplant, in general, the most salt-tolerant of the three Solanaceae crops. These findings suggest that salt-tolerant eggplant cultivars could potentially be used as rootstocks for more salt-sensitive tomato cultivars. Besides salinity tolerance, some eggplant cultivars also offer other benefits over tomato rootstocks, such as resistance to different bacterial wilts (Ralstonia solanacearum or Pseudomonas solanacearum), which can cause up to $100 \%$ economic losses in tomato crops ${ }^{59}$. It also should be noted that although 'Black Beauty' had the lowest relative yield under the salinity tested $\left(\mathrm{EC}_{\mathrm{iw}}=4.0 \mathrm{dS} \mathrm{m}^{-1}\right)$, it still had the significantly greatest fruit yield among eggplant cultivars under salinity, suggesting that it still could be a feasible cultivar to be used under moderate irrigation water salinities.

Tomatoes are well adapted to a variety of climates and are widely distributed in habitats ranging from the arid Pacific coast at sea level to altitudes above $3000 \mathrm{~m}$ above sea level in the Andes with its wild species reported as native to Bolivia, Peru, Ecuador, Chile, Colombia, and Galapagos Islands ${ }^{60}$. Despite its wide genetic variability, little progress has been made towards establishing tomato cultivars that are tolerant to salinity. In our study, the most salt-tolerant tomato cultivars were 'Red Pear' and 'Yellow Pear'. These results were surprising as we expected other cultivars, especially 'Thessalonniki' (from Greece) and possibly 'Jaune Flamme' (France), to be most salt-tolerant as both are from Mediterranean, semi-arid climates. However, these two were the most saltsensitive cultivars.

As might be expected, 'Orange Habanero' (Capsicum chinense Jacq.), which originated from low-salinity Amazonian regions, had the weakest mechanism of controlling $\mathrm{Na}$ transport from roots to shoots. At the same time, all other cultivars belonging to C. annuum, and believed to have their center of origin in semi-arid Mexico, had similar capabilities to restrict $\mathrm{Na}$ to their roots and prevent its translocation to the shoots. Crossing (or grafting) Capsicum chinense with (or onto) a more salt-tolerant C. annuum cultivar (e.g., 'Thai Hot' or 'Ancho') could potentially make 'Orange Habanero' more tolerant to salinity. 
Response to salinity differed significantly among species and cultivars. The most sensitive tomato 'Jaune Flamme', exhibited leaf $\mathrm{K}$ deficiency under the salt treatment. The most salt-tolerant pepper cultivars of the species Capsicum annum were 'Thai Hot' with high leaf $\mathrm{Na}$ and low leaf $\mathrm{Cl}$ and 'Ancho', with relatively high root $\mathrm{K}$. The most sensitive cultivar, 'Corbaci', was characterized by high leaf $\mathrm{Ca}$ and $\mathrm{Mg}$ and high root $\mathrm{Cl}$.

Expression analysis revealed that salinity treatment-specific induction of genes was more important than genotype-specific expression in Solanaceae. The differences in relative yield were not explainable by one single mechanism, but rather by multi-component traits that were critical during salinity stress. The primary component traits included the ability to exclude $\mathrm{Na}$, restrict $\mathrm{Na}$ transport to leaves, sequester $\mathrm{Na}^{+}$and $\mathrm{Cl}^{-}$in vacuoles, and accumulate $\mathrm{K}$.

Evaluation of heirloom cultivars of diverse geographic origins under field conditions in the dry and hot semiarid climate of southern California provided us with a unique opportunity to genetically characterize these genotypes for their salinity tolerance. Understanding the genetic networks involved in salinity tolerance in Solanaceae will provide additional tools for breeders to develop varieties for regions affected by high salinity.

\section{Materials and methods}

Plant material. A field experiment was conducted at the U.S. Salinity Laboratory in Riverside, California, from March 2018 to October 2018 to evaluate the salt tolerance of 8 different eggplant cultivars, 8 different tomato, and 8 different peppers cultivars. Most of the plants of 'Cherokee Purple' cultivar of tomato died due to disease; hence this cultivar was eliminated and only 7 tomato cultivars were used for the analyses. Heirloom cultivars of eggplant (Solanum melongena L.) that were tested were: 'Bangladeshi Long, 'Black Beauty', 'Kazakhstan', 'Listada de Gandia, 'Long Purple', 'Ping Tung,' 'Tadifi', and 'Turkish Orange.' The peppers tested were (mostly Capsicum annuum L.): 'Ajvarski, 'Ancho' (Poblano), 'California Wonder', 'Corbaci, 'Costa Rican' (a sweet hybrid), 'Orange Habanero' pepper (Capsicum chinense L.), 'Jimmy Nardello', and 'Thai Hot'. The tomato heirlooms that were tested were: 'Bloody Butcher,' 'Cherokee Purple, 'Garden Delight', 'Jaune Flamme, 'Quarter Century', 'Red Pear,' 'Thessaloniki', and 'Yellow Pear'.

Experimental design and treatments. The experiment consisted of 576 plants (192 plants of each species) arranged in a split-plot design with two salt levels in the main plots arranged in randomized complete blocks with three replications. Plants were transplanted in May 2018 with 32 plants per row and a total of 18 rows. Seedlings were established one month earlier in the greenhouse under non-saline conditions. The rows were irrigated with non-saline irrigation water (control was Riverside city tap water with $\mathrm{EC}_{\mathrm{iw}}=0.65 \mathrm{dS} \mathrm{m}^{-1}$ ) and saline water $\left(\mathrm{EC}_{\mathrm{iw}}=4.0 \mathrm{dS} \mathrm{m} \mathrm{m}^{-1}\right)$. Each plant was irrigated using one pressure compensated $2 \mathrm{~L} \mathrm{~h}^{-1} \mathrm{micro}^{-}$ sprinkler. The saline water composition consisted of mixed salts giving a composition, of $\mathrm{Ca}=10.9, \mathrm{Mg}=7.5$, $\mathrm{Na}=21.4, \mathrm{~K}=1.0$, sulfate $=12.9, \mathrm{Cl}=27.5$ and $\mathrm{NO}_{3}{ }^{-}=0.4$, where concentrations are expressed in $\mathrm{mmol}_{\mathrm{c}} \mathrm{L}^{-1}$. Before planting, $500 \mathrm{~g}$ of dried steer manure was incorporated into the soil used to fill each of the holes augered into the field for accepting transplants.

Irrigation management. The field plot was irrigated once to two times a day with frequency and time intervals depending on the water requirements. From June to October, each plant received between 1 and $2.26 \mathrm{~L}$ per day on non-raining days. When a rain event occurred, irrigation was adjusted accordingly. Each plant was fertilized with $10 \mathrm{~g}$ of Osmocote Plus (a slow-release fertilizer with $\mathrm{N}-15 \%, \mathrm{P}-9 \%, \mathrm{~K}-12 \%, \mathrm{Mg}-1.3 \%$, $\mathrm{S}-6 \%, \mathrm{~B}-0.02 \%, \mathrm{Cu}-0.05 \%, \mathrm{Fe}-0.46 \%, \mathrm{Mn}-0.06 \%, \mathrm{Mo}-0.02 \%, \mathrm{Zn}-0.05 \%$ by weight) in August of 2018. The local CMIS weather station data indicated that for the experimental period, the potential reference crop ET $\left(\mathrm{ET}_{0}\right)$ was $8.31,20.42,18.67,14.88$, and $10.9 \mathrm{~cm}$ for June, July, August, September, and October, respectively. The corresponding total water applications were $13,62.3,70.1,60.0$, and $47.1, \mathrm{~L} /$ plant, respectively. We estimate a canopy cover of 0.5 and a crop coefficient factor of 1.5 to account for the water requirements of plants grown in a small plot environment. The estimated leaching fraction was thus calculated as an average of 0.37 over the experimental period. Using the relationship between irrigation water salinity and leaching fraction, the average rootzone salinity, expressed as EC saturation extract, was calculated as $3.7 \mathrm{dS} \mathrm{m}^{-1}$ for the saline treatment.

Plant measurements. Fruit yields of each plant were collected weekly from July to October, from which we calculated the average fruit weight per plant. A composite sample of 9-30 fully expanded leaves for each cultivar and each treatment were collected in September 2018. Samples were weighed, washed, oven-dried, reweighed, microwave digested, and subsequently analyzed for $\mathrm{Ca}, \mathrm{Mg}, \mathrm{Na}, \mathrm{K}, \mathrm{P}, \mathrm{S}, \mathrm{Fe}, \mathrm{Cu}, \mathrm{Mn}$, and $\mathrm{Zn}$ by Perkin Elmer Optima 3300 DV ICP OES (WinLab 32, 2010). Chloride concentrations were determined by wet digestion of the plant material and then analyzed by an amperometric chloride titrator. A composite sample of roots of each cultivar from each row was taken between October 30th to November 1st and analyzed as described above.

Statistical analysis. The SAS/STAT ${ }^{\varpi}$ software package was used for three-way analyses of variance (ANOVA), followed by Tukey and Tukey-Kramer pair-wise comparison of means. Differences with an alpha $=0.05$ or less were considered significant. ANOVA and Tukey's test were used to analyze multiple variables using the general linear model proc GLM. We also used the CORR procedure to perform correlation analyses.

Primer design for expression analyses. Genes involved in $\mathrm{Na}^{+}$and $\mathrm{Cl}^{-}$transport were identified using functional conservation with the genes identified in Arabidopsis ${ }^{29}$. Basic Local Alignment Search Tool (BLAST) analysis was utilized to identify corresponding genes in eggplant, tomato, and pepper. The gene with the high- 
est homology was used to design primers for qRT-PCR analyses. To ensure no nonspecific amplification from contaminating DNA, at least one was designed from two exons flanking an intron.

Expression analyses. Leaf and root tissue samples were harvested from one salt-tolerant and one saltsensitive cultivar each of eggplant, tomato, and pepper ( 2 cultivars $\times 3$ crops $\times 2$ tissue types $\times 3$ replications $\times 2$ salinity levels), $48 \mathrm{~h}$ after initiation of salinity treatment. Young tissue samples were frozen immediately in liquid nitrogen, and RNA was isolated using TRIzol reagent (Invitrogen, Carlsbad, CA, USA). From isolated RNA, contaminating DNA was removed using DNase I, following the manufacturer's instructions (Thermo Scientific, Waltham, MA, USA). The qRT-PCR experiment was conducted using iTaq Universal SYBR Green One-Step Kit in BioRad CFX96 system (Bio-Rad Laboratories, Hercules, CA, USA). For qRT-PCR reactions, $10 \mu \mathrm{L}$ volume was used that contained $100 \mathrm{ng}$ total RNA, $0.125 \mu \mathrm{L}$ iScript Reverse Transcriptase, $0.75 \mu \mathrm{M}$ of each of the primers, and $5 \mu \mathrm{l}$ of $2 \times$ one-step SYBR Green Reaction mix. The PCR reactions were carried out using the following program: $50^{\circ} \mathrm{C}$ for $10 \mathrm{~min}, 95^{\circ} \mathrm{C}$ for $1 \mathrm{~min}$, then 40 cycles of $95^{\circ} \mathrm{C}$ denaturation for $10 \mathrm{~s}, 57^{\circ} \mathrm{C}$ annealing for $30 \mathrm{~s}$, and $68^{\circ} \mathrm{C}$ extension for $30 \mathrm{~s}$. Four samples were used as inter-plate controls for normalization of expression in different plates. Cyclophilin (AF126551), 18S ribosomal RNA (X67238), and glyceraldehyde-3-phosphate dehydrogenase (U17005) were used as reference genes for eggplant. Actin (TC194780), protein phosphatase 2A catalytic subunit (AY325817), and ribosomal protein L2 (X64562) were used as reference genes for tomato. Actin (GQ339766), glyceraldehyde-3-phosphate dehydrogenase (AJ246009), and EF1a (AY496125) were used as reference genes for pepper. Relative expression of each gene was determined by comparing the cycle threshold of each gene to the reference genes, and differentially expressed genes were identified. To test the amplification specificity, melt curve analysis was used by ramping the temperature to $95^{\circ} \mathrm{C}$ for $10 \mathrm{~s}$, then back to $65^{\circ} \mathrm{C}$ for $5 \mathrm{~s}$, followed by incremental increases of $0.5^{\circ} \mathrm{C} /$ cycle up to $95^{\circ} \mathrm{C}$.

The use of plants in the present study complies with international, national and/or institutional guidelines.

\section{Data availability}

All data supporting this study are included in the article and its supplementary material.

Received: 14 June 2021; Accepted: 27 July 2021

Published online: 11 August 2021

\section{References}

1. Rodell, M. et al. Emerging trends in global freshwater availability. Nature 557, 651-659. https://doi.org/10.1038/s41586-018-0123-1 (2018).

2. Jasechko, S. \& Perrone, D. Global groundwater wells at risk of running dry. Science 372, 418-421. https://doi.org/10.1126/scien ce.abc2755 (2021).

3. Famiglietti, J. S. \& Ferguson, G. The hidden crisis beneath our feet. Science 372, 344-345. https://doi.org/10.1126/science.abh28 67 (2021).

4. Samuels, J. Biodiversity of food species of the Solanaceae family: A preliminary taxonomic inventory of subfamily Solanoideae. Resources 4, 277-322. https://doi.org/10.3390/resources4020277 (2015).

5. Assaha, D. V. M., Ueda, A. \& Saneoka, H. Comparison of growth and mineral accumulation of two solanaceous species Solanum scabrum Mill. (huckleberry) and S. melongena L. (eggplant), under salinity stress. Soil Sci. Plant Nutr. 59, 912-920. https://doi. org/10.1080/00380768.2013.858300 (2013).

6. Grieve, C. M., Grattan, S. R. \& Maas, E. V. In ASCE Manuals and Reports on Engineering Practice No. 71. Agricultural Salinity Assessment and Management (eds Wallender, W. W. \& Tanji, K. K.) 405-459 (ASCE, 2012).

7. Giuffrida, F., Cassaniti, C. \& Leonardi, C. Tomato and eggplant scions influence the effect of rootstock under $\mathrm{Na}_{2} \mathrm{SO}_{4}$ salinity. Acta Agic. Scand. B Soil Plant Sci. 64, 700-709. https://doi.org/10.1080/09064710.2014.953989 (2014).

8. Flowers, T. J. Improving crop salt tolerance. J. Exp. Bot. 55, 307-319. https://doi.org/10.1093/jxb/erh003 (2004).

9. Hanachi, S., Van Labeke, M. C. \& Mehouachi, T. Application of chlorophyll fluorescence to screen eggplant (Solanum melongena L.) cultivars for salt tolerance. Photosynthetica 52, 57-62. https://doi.org/10.1007/s11099-014-0007-z (2014).

10. Heuer, B., Meiri, A. \& Shalevet, J. Salt tolerance of eggplant. Plant Soil 95, 9-13 (1986).

11. Ünlükara, A., Kurunç, A., Kesmez, G. D., Yurtseven, E. \& Suarez, D. L. Effects of salinity on eggplant (Solanum melongena L.) growth and evapotranspiration. Irrig. Drain. 59, 203-214. https://doi.org/10.1002/ird.453 (2010).

12. Abbas, W., Ashraf, M. \& Akram, N. A. Alleviation of salt-induced adverse effects in eggplant (Solanum melongena L.) by glycinebetaine and sugarbeet extracts. Sci. Hortic. 125, 188-195. https://doi.org/10.1016/j.scienta.2010.04.008 (2010).

13. Mitchell, J. P., Shennan, C., Grattan, S. R. \& May, D. M. Tomato fruit yields and quality under water deficit and salinity. J. Am. Soc. Hortic. Sci. 116, 215. https://doi.org/10.21273/jashs.116.2.215 (1991).

14. Parra, M., Albacete, A., Martínez-Andújar, C. \& Pérez-Alfocea, F. Increasing plant vigour and tomato fruit yield under salinity by inducing plant adaptation at the earliest seedling stage. Environ. Exp. Bot. 60, 77-85. https://doi.org/10.1016/j.envexpbot.2006. $06.005(2007)$

15. Turhan, A., Seniz, V. \& Kwscu, H. Genotypic variation in the response of tomato to salinity. Afr. J. Biotechnol. 8, 1062-1068. https:// doi.org/10.4314/AJB.V8I6.60015 (2009).

16. Cuartero, J., Bolarín, M. C., Asíns, M. J. \& Moreno, V. Increasing salt tolerance in the tomato. J. Exp. Bot. 57, 1045-1058. https:// doi.org/10.1093/jxb/erj102 (2006).

17. Chinn, M. S., Sharma-Shivappa, R. R. \& Cotter, J. L. Solvent extraction and quantification of capsaicinoids from Capsicum chinense. Food Bioprod. Process. 89, 340-345. https://doi.org/10.1016/j.fbp.2010.08.003 (2011).

18. Kulkarni, Y. A., Suryavanshi, S. V., Auti, S. T. \& Gaikwad, A. B. In Nutritional Modulators of Pain in the Aging Population (eds Watson, R. R. \& Zibadi, S.) 107-119 (Academic Press, 2017).

19. Giorio, P. et al. Physiological basis of salt stress tolerance in a landrace and a commercial variety of sweet pepper (Capsicum annuum L.). Plants (Basel, Switzerland) 9, 795. https://doi.org/10.3390/plants9060795 (2020).

20. Ahmadi, M. \& Souri, M. K. Growth characteristics and fruit quality of chili pepper under higher electrical conductivity of nutrient solution induced by various Salts. AGRIVITA J. Agric. Sci. 42, 143-152. https://doi.org/10.17503/agrivita.v42i1.2225 (2020).

21. Penella, C. et al. Some rootstocks improve pepper tolerance to mild salinity through ionic regulation. Plant Sci. 230, 12-22. https:// doi.org/10.1016/j.plantsci.2014.10.007 (2015).

22. Semiz, G. D. \& Suarez, D. L. Tomato salt tolerance: Impact of grafting and water composition on yield and ion relations. Turk. J. Agric. For. 39, 876-886. https://doi.org/10.3906/tar-1412-106 (2015). 
23. Semiz, G. D. \& Suarez, D. L. Impact of grafting, salinity and irrigation water composition on eggplant fruit yield and ion relations. Sci. Rep. 9, 19373. https://doi.org/10.1038/s41598-019-55841-0 (2019).

24. Ors, S. \& Suarez, D. L. Salt tolerance of spinach as related to seasonal climate. Hort. Sci. (Prague) 43, 33-41. https://doi.org/10. 17221/114/2015-HORTSCI (2016).

25. Grattan, S. R. \& Grieve, C. M. Salinity-mineral nutrient relations in horticultural crops. Sci. Hort. 78, 127-157. https://doi.org/ 10.1016/S0304-4238(98)00192-7 (1998).

26. Ors, S. \& Suarez, D. L. Spinach biomass yield and physiological response to interactive salinity and water stress. Agric. Water Manag. 190, 31-41. https://doi.org/10.1016/j.agwat.2017.05.003 (2017).

27. Zurayk, R., Nimah, M. \& Hamzé, M. The salt tolerance potential of local cultivars of eggplant (Solanum melongena L.). Biol. Agric. Hortic. 9, 317-324. https://doi.org/10.1080/01448765.1993.11978502 (1993).

28. Dwivedi, S., Goldman, I. \& Ortiz, R. Pursuing the potential of heirloom cultivars to improve adaptation, nutritional, and culinary features of food crops. Agronomy 9, 441. https://doi.org/10.3390/agronomy9080441 (2019).

29. Munns, R. \& Tester, M. Mechanisms of salinity tolerance. Annu. Rev. Plant Biol. 59, 651-681. https://doi.org/10.1146/annurev. arplant.59.032607.092911 (2008).

30. Sandhu, D. \& Kaundal, A. In Biotechnologies of Crop Improvement, Volume 3: Genomic Approaches (eds Gosal, S. S. \& Wani, S. H.) 25-40 (Springer, 2018).

31. Li, B., Tester, M. \& Gilliham, M. Chloride on the move. Trends Plant Sci 22, 236-248. https://doi.org/10.1016/j.tplants.2016.12. 004 (2017).

32. Li, J. et al. Comparative transcriptome analysis reveals $\mathrm{K}^{+}$transporter gene contributing to salt tolerance in eggplant. BMC Plant Biol. 19, 67. https://doi.org/10.1186/s12870-019-1663-8 (2019).

33. Belver, A., Olías, R., Huertas, R. \& Rodríguez-Rosales, M. P. Involvement of SlSOS2 in tomato salt tolerance. Bioengineered 3 , 298-302. https://doi.org/10.4161/bioe.20796 (2012).

34. Assaha, D. V. M., Mekawy, A. M. M., Ueda, A. \& Saneoka, H. Salinity-induced expression of HKT may be crucial for Na ${ }^{+}$exclusion in the leaf blade of huckleberry (Solanum scabrum Mill.), but not of eggplant (Solanum melongena L.). Biochem. Biophys. Res. Commun. 460, 416-421. https://doi.org/10.1016/j.bbrc.2015.03.048 (2015).

35. Zhang, H. X. et al. Transcription factor CaSBP12 negatively regulates salt stress tolerance in pepper (Capsicum annuum L.). Int. J. Mol. Sci. https://doi.org/10.3390/ijms21020444 (2020).

36. Wang, L. et al. The abiotic stress-responsive NAC transcription factor SINAC11 is involved in drought and salt response in tomato (Solanum lycopersicum L.). Plant Cell Tiss. Org. 129, 161-174. https://doi.org/10.1007/s11240-017-1167-x (2017).

37. Brenes, M. et al. Physiological and biochemical responses to salt stress in cultivated eggplant (Solanum melongena L.) and in $S$. insanum L., a close wild relative. Agronomy 10, 651 (2020).

38. Sandhu, D. et al. Linking diverse salinity responses of 14 almond rootstocks with physiological, biochemical, and genetic determinants. Sci. Rep. 10, 21087. https://doi.org/10.1038/s41598-020-78036-4 (2020).

39. Muñoz-Ramírez, L. S. et al. Selection of Habanero pepper F1 hybrids (Capsicum chinense Jacq.) at the Yucatan Peninsula, Mexico with a high potential for different markets. Agriculture 10, 478. https://doi.org/10.3390/agriculture10100478 (2020).

40. Wahyuni, Y., Ballester, A. R., Sudarmonowati, E., Bino, R. J. \& Bovy, A. G. Metabolite biodiversity in pepper (Capsicum) fruits of thirty-two diverse accessions: Variation in health-related compounds and implications for breeding. Phytochemistry 72, 1358-1370. https://doi.org/10.1016/j.phytochem.2011.03.016 (2011).

41. Smith, P. G. \& Heiser, C. B. Taxonomy of Capsicum sinense Jacq. and the geographic distribution of the cultivated Capsicum Species. Bull. Torrey Bot. Club 84, 413-420. https://doi.org/10.2307/2482971 (1957).

42. Irion, G. Soil infertility in the Amazonian rain forest. Naturwissenschaften 65, 515-519. https://doi.org/10.1007/BF00439791 (1978).

43. Kraft, K. H. et al. Multiple lines of evidence for the origin of domesticated chili pepper, Capsicum annuum, in Mexico. Proc. Natl. Acad. Sci. U.S.A. 111, 6165-6170. https://doi.org/10.1073/pnas.1308933111 (2014).

44. Ragel, P., Raddatz, N., Leidi, E. O., Quintero, F. J. \& Pardo, J. M. Regulation of $\mathrm{K}^{+}$nutrition in plants. Front. Plant Sci. 10, $281-281$. https://doi.org/10.3389/fpls.2019.00281 (2019).

45. Almeida, D. M., Oliveira, M. M. \& Saibo, N. J. M. Regulation of $\mathrm{Na}^{+}$and $\mathrm{K}^{+}$homeostasis in plants: Towards improved salt stress tolerance in crop plants. Genet. Mol. Biol. 40, 326-345. https://doi.org/10.1590/1678-4685-GMB-2016-0106 (2017).

46. Sandhu, D., Cornacchione, M. V., Ferreira, J. F. \& Suarez, D. L. Variable salinity responses of 12 alfalfa genotypes and comparative expression analyses of salt-response genes. Sci. Rep. 7, 42958. https://doi.org/10.1038/srep42958 (2017).

47. Maggio, A., Raimondi, G., Martino, A. \& De Pascale, S. Salt stress response in tomato beyond the salinity tolerance threshold. Environ. Exp. Bot. 59, 276-282. https://doi.org/10.1016/j.envexpbot.2006.02.002 (2007).

48. Li, Y. Physiological responses of tomato seedlings (Lycopersicon esculentum) to salt stress. Mod. Appl. Sci. 3, 171-176. https://doi. org/10.5539/mas.v3n3p171 (2009).

49. Wang, X. et al. Growth, photosynthesis, solute accumulation, and ion balance of tomato plant under sodium- or potassium-salt stress and alkali stress. Agron. J. 107, 651-661. https://doi.org/10.2134/agronj14.0344 (2015).

50. Lopez, M. V. \& Satti, S. M. E. Calcium and potassium-enhanced growth and yield of tomato under sodium chloride stress. Plant Sci. 114, 19-27. https://doi.org/10.1016/0168-9452(95)04300-4 (1996).

51. Rush, D. W. \& Epstein, E. Genotypic responses to salinity. Plant Physiol. 57, 162-166. https://doi.org/10.1104/pp.57.2.162 (1976).

52. Marschner, P. \& Rengel, Z. In Marschner's Mineral Nutrition of Higher Plants Vol. 12 (ed. Marschner, P.) 315-330 (Academic Press, 2012).

53. Psarras, G., Bertaki, M. \& Chartzoulakis, K. Response of greenhouse tomato to salt stress and $\mathrm{K}^{+}$supplement. Plant Biosyst. 142, 149-153. https://doi.org/10.1080/11263500701872903 (2008).

54. Günes, A., Inal, A. \& Alpaslan, M. Effect of salinity on stomatal resistance, proline, and mineral composition of pepper. J. Plant Nutr. 19, 389-396. https://doi.org/10.1080/01904169609365129 (1996).

55. Akinci, I. E., Akinci, S., Yilmaz, K. \& Dikici, H. Response of eggplant varieties (Solanum melongena) to salinity in germination and seedling stages. N. Z. J. Crop Hortic. 32, 193-200. https://doi.org/10.1080/01140671.2004.9514296 (2004).

56. Hannachi, S. \& Van Labeke, M.-C. Salt stress affects germination, seedling growth and physiological responses differentially in eggplant cultivars (Solanum melongena L.). Sci. Hortic. 228, 56-65. https://doi.org/10.1016/j.scienta.2017.10.002 (2018).

57. Tester, M. \& Davenport, R. $\mathrm{Na}^{+}$tolerance and $\mathrm{Na}^{+}$transport in higher plants. Ann. Bot. 91, 503-527. https://doi.org/10.1093/aob/ mcg058 (2003).

58. Weese, T. L. \& Bohs, L. Eggplant origins: Out of Africa, into the orient. Taxon 59, 49-56. https://doi.org/10.2307/27757050 (2010).

59. Manickam, R., Chen, J.-R., Sotelo-Cardona, P., Kenyon, L. \& Srinivasan, R. Evaluation of different bacterial wilt resistant eggplant rootstocks for grafting tomato. Plants 10, 75. https://doi.org/10.3390/plants10010075 (2021).

60. Vargas, J. E. E., Aguirre, N. C. \& Coronado, Y. M. Study of the genetic diversity of tomato (Solanum spp.) with ISSR markers. Rev. Ceres. 67, 199-206. https://doi.org/10.1590/0034-737X202067030005 (2020).

\section{Acknowledgements}

This research was funded by the United States Department of Agriculture-Agricultural Research Service, National Program 301: Plant Genetic Resources, Genomics, and Genetic Improvement (project number 
2036-13210-012-00-D). Acknowledgments are due to Dr. Manju Pudussery for the help with expression analyses and Ms. Pangki Xiong for the ion analyses.

\section{Author contributions}

D.L.S., D.S. and J.F. conceptualized, designed, and supervised the experiments; N.C. evaluated the genotypes. TR conducted the expression analyses; D.L.S., D.S., J.F. and N.C. analyzed and interpreted the data; The manuscript was written jointly with contributions from all the authors. All authors have read and approved the manuscript.

\section{Competing interests}

The authors declare no competing interests.

\section{Additional information}

Supplementary Information The online version contains supplementary material available at https://doi.org/ 10.1038/s41598-021-95506-5.

Correspondence and requests for materials should be addressed to D.S.

Reprints and permissions information is available at www.nature.com/reprints.

Publisher's note Springer Nature remains neutral with regard to jurisdictional claims in published maps and institutional affiliations.

(c) (1) Open Access This article is licensed under a Creative Commons Attribution 4.0 International License, which permits use, sharing, adaptation, distribution and reproduction in any medium or format, as long as you give appropriate credit to the original author(s) and the source, provide a link to the Creative Commons licence, and indicate if changes were made. The images or other third party material in this article are included in the article's Creative Commons licence, unless indicated otherwise in a credit line to the material. If material is not included in the article's Creative Commons licence and your intended use is not permitted by statutory regulation or exceeds the permitted use, you will need to obtain permission directly from the copyright holder. To view a copy of this licence, visit http://creativecommons.org/licenses/by/4.0/.

(C) This is a U.S. Government work and not undercopyright protection in the US; foreign copyright protection may apply 2021 